\title{
A Smart Phosphine-Diyne Polymer Displays “Turn-on” Emission with a High Selectivity for Gold(I/III) Ions
}

\author{
Harvey K. Mackenzie, Benjamin W. Rawe, Kerim Samedov, Henry T. G. Walsgrove, \\ Azalea Uva, Zeyu Han and Derek P. Gates* \\ Department of Chemistry, University of British Columbia, 2036 Main Mall, \\ Vancouver, British Columbia, Canada, V6T 1 Z1.
}

Email: dgates@chem.ubc.ca

\section{Equipment}

${ }^{1} \mathrm{H},{ }^{31} \mathrm{P}\left\{{ }^{1} \mathrm{H}\right\},{ }^{13} \mathrm{C}\left\{{ }^{1} \mathrm{H}\right\}$ NMR spectra were recorded at $25^{\circ} \mathrm{C}$ on Bruker Avance 300,400 or 600 MHz spectrometers. $\mathrm{H}_{3} \mathrm{PO}_{4}(85 \%)$ was used as an external standard ( $\delta=0$ for $\left.{ }^{31} \mathrm{P}\right) .{ }^{1} \mathrm{H}$ NMR spectra were referenced to the residual protonated solvent signal and ${ }^{13} \mathrm{C}\left\{{ }^{1} \mathrm{H}\right\}$ NMR spectra were referenced to the deuterated solvent signal. Elemental analyses were performed in the University of British Columbia Chemistry Microanalysis Facility. Mass spectra were recorded on a Kratos MS 50 instrument in EI mode $(70 \mathrm{eV})$. Polymer molecular weights were determined by gel permeation chromatography (GPC) using an Agilent liquid chromatograph equipped with an Agilent 1200 series isocratic pump, Agilent 1200 series standard autosampler, Phenomenex Phenogel $5 \mathrm{~mm}$ narrow bore columns $(4.6 \times 300 \mathrm{~mm})$ $10^{4} \AA$ (5000-500 $\left.000 \mathrm{~g} \mathrm{~mol}^{-1}\right), 500 \AA$ (1000-15 $\left.000 \mathrm{~g} \mathrm{~mol}^{-1}\right)$, and $10^{3} \AA$ (1000-75 $000 \mathrm{~g} \mathrm{~mol}^{-}$ $\left.{ }^{1}\right)$, Wyatt Optilab T-rEx differential refractometer $\left(\lambda=658 \mathrm{~nm}, 40{ }^{\circ} \mathrm{C}\right)$. A flow-rate of $0.5 \mathrm{~mL}$ min $^{-1}$ was used and samples were dissolved in THF (ca. $2 \mathrm{mg} \mathrm{mL}^{-1}$ ). Molecular weights were determined in comparison to polystyrene standards. Absorption spectra were obtained in THF on a Varian Cary 5000 UV-Vis-near-IR spectrophotometer using a $1 \mathrm{~cm}$ quartz cuvette. Solution state fluorescence and excitation spectra were obtained in THF on a Horiba scientific Fluoromax-4 spectrofluorometer using a $1 \mathrm{~cm}$ quartz cuvette. Solution state quantum yields were calculated vs. anthracene as a standard $\left(\Phi=0.27\right.$ in ethanol). ${ }^{1}$ Solutions for emission lifetime studies were prepared in a glovebox using freshly distilled degased THF. Emission lifetime data were performed using a Horiba Yvon Fluorocube TCSPC apparatus. A $370 \mathrm{~nm}$ NanoLED source pulsing at a repetition rate of $50-100 \mathrm{kHz}$ was used for excitation. Broadband emission was monitored by a CCD detector at wavelengths $>400 \mathrm{~nm}$ using a low pass filter. Data were fitted using the DAS6 Data Analysis software package.

\section{Materials and Methods}

All manipulations of air- and/or water-sensitive compounds were performed under a nitrogen atmosphere by using standard Schlenk or glovebox techniques. Hexanes, dichloromethane and toluene were deoxygenated with nitrogen and dried by passing through a column containing activated alumina. Tetrahydrofuran (THF) was dried over sodium and benzophenone, and was distilled prior to use. Ethanol and methanol was degassed before use. Triethylamine was dried over calcium hydride and was distilled before use. Nickel (II) acetylacetonate (Aldrich) and anthracene (Fisher) were sublimed before use. 
$\mathrm{Au}$ (tht)Cl,2 1,4-diethynyl-2,5- $n$-hexylbenzene,3 2,7-diethynyl-9,9-dihexyl-9H-fluorene ${ }^{4}$ and 2,7-diethynyl-9,9-dimethyl-9H-fluorene ${ }^{5}$ were made following literature procedures.

\section{Synthesis}

\section{Preparation of 1}

Under $\mathrm{N}_{2}$, a Schlenk flask was charged with phenyldichlorophosphine $(0.56 \mathrm{~g}, 3.1 \mathrm{mmol})$, 1,4 diethynyl-2,5-di- $n$-hexylbenzene $(0.69 \mathrm{~g}, 2.4 \mathrm{mmol}), 2,7$-diethynyl-9,9-di- $n$-hexyl- $9 H$ fluorene $(0.30 \mathrm{~g}, 0.78 \mathrm{mmol})$, triethylamine $(2.6 \mathrm{~mL}, 19 \mathrm{mmol})$, nickel (II) acetylacetonate $(20 \mathrm{mg}, 78 \mu \mathrm{mol})$ and toluene $(10 \mathrm{~mL})$ (concentration of reaction mixture $=0.24 \mathrm{M})$. The reaction mixture was heated to $85{ }^{\circ} \mathrm{C}$ and was stirred vigorously for $16 \mathrm{~h}$. After this time volatiles were removed under reduced pressure. THF $(2.0 \mathrm{~mL})$ was added to the deep red solid to afford a viscous solution. To this viscous solution was added $200 \mathrm{~mL}$ of degassed methanol to precipitate the polymer. The solvent was removed and the precipitation method was repeated with ethanol $(200 \mathrm{~mL}$ degassed ethanol into $2 \mathrm{~mL}$ THF solution of polymer). Finally the polymer residue was dissolved in THF (ca. $5 \mathrm{~mL}$ ) and $200 \mathrm{~mL}$ methanol was added, leaving a deep red solid that was dried under vacuum overnight. Yield $=0.84 \mathrm{~g}(64 \%)$.

${ }^{31} \mathrm{P}\left\{{ }^{1} \mathrm{H}\right\}$ NMR $\left(121 \mathrm{MHz}, \mathrm{CDCl}_{3}\right): \delta-59.6(\mathrm{br}, 1 \mathrm{P}),-60.0(7 \mathrm{P}),-60.5(8 \mathrm{P}) ;{ }^{1} \mathrm{H}$ NMR $(400 \mathrm{MHz}$, $\mathrm{CDCl}_{3}$ ): $\delta$ 8.02-7.80 (br, $1 \mathrm{H}$, aryl H), 7.68-7.61 (br, $1 \mathrm{H}$, aryl H) 7.57-7.36 (br, 3H, aryl H) 7.377.29 (br, $2 \mathrm{H}$, aryl H), 3.31 (s, $\mathrm{C} \equiv \mathrm{CH}$ end group), 2.79-2.60 (br, $2 \mathrm{H}, \mathrm{PhC}^{\mathrm{C}} \mathrm{CH}_{2}$ ), 2.00-1.88 (br, FluC-CH${ }_{2}$ ), 1.67-1.46 (br, 2H, $\mathrm{CH}_{2}$ ), 1.40-1.16 (br, 8H, $\mathrm{CH}_{2}$ ), 1.12-0.95 (br, 4H), 0.94-0.65 (br $\left.\mathrm{m}, 4.5 \mathrm{H}, \mathrm{CH}_{3}\right), 0.61-0.49$ (br, $\left.1.5 \mathrm{H} \mathrm{CH} \mathrm{CH}_{3}\right) .{ }^{13} \mathrm{C}\left\{{ }^{1} \mathrm{H}\right\} \mathrm{NMR}\left(151 \mathrm{MHz}, \mathrm{CDCl}_{3}\right): \delta 151.1$ (Fluorene aryl C)142.9 (aryl C),141.2 (aryl C) 132.4 (br, aryl C), 131.3 (aryl C), 129.6 (aryl C), 128.8 (br, aryl C), 126.3 (aryl C), 122.5 (br, P-C $\equiv \mathrm{C}-C_{A r}$ ), 122.2 (br, P-C $\equiv \mathrm{C}-C_{A r}$ ), $121.3\left(\mathrm{br}, \mathrm{P}-\mathrm{C} \equiv \mathrm{C}-C_{A r}\right.$ ), 122.0 (br, $\mathrm{P}-\mathrm{C} \equiv \mathrm{C}-C_{A r}$ ), 107.3 (br, $\mathrm{P}-\mathrm{C} \equiv C-\mathrm{C}_{\mathrm{Ar}}$ ), 104.9 (br, $\mathrm{P}-\mathrm{C} \equiv C-\mathrm{C}_{\mathrm{Ar}}$ ), 87.8 (br, m, P-C $\equiv \mathrm{C}-\mathrm{C}_{\mathrm{Ar}}$ ), $83.0\left(\mathrm{Flu}_{\mathrm{Ar}}-\mathrm{C} \equiv \mathrm{CH}\right) \quad 82.2\left(\mathrm{~s},{ }^{{ }^{2 h}} \mathrm{C}_{\mathrm{Ar}}-\mathrm{C} \equiv \mathrm{CH}\right), 81.8\left(\mathrm{~s}, \mathrm{Ph}_{\mathrm{Ar}}-\mathrm{C} \equiv C \mathrm{H}\right), 55.3\left(\mathrm{Flu}_{\mathrm{Ar}}-\mathrm{C}\left(\mathrm{CH}_{2}\right)_{2}\right), 40.3$ $\left(\mathrm{CH}_{2}\right), 34.0\left(\mathrm{CH}_{2}\right) 33.8\left(\mathrm{CH}_{2}\right), 31.6\left(\mathrm{CH}_{2}\right), 31.5\left(\mathrm{CH}_{2}\right), 30.6\left(\mathrm{CH}_{2}\right), 29.6\left(\mathrm{CH}_{2}\right), 29.1\left(\mathrm{CH}_{2}\right), 23.6$ $\left(\mathrm{CH}_{2}\right), 22.6\left(\mathrm{CH}_{2}\right), 14.1\left(\mathrm{CH}_{3}\right)$. GPC (vs. polystyrene): $M_{\mathrm{n}}=3,600 \mathrm{~g} \mathrm{~mol}^{-1}, Ð=2.2$.

\section{Preparation of 1.0}

To a rapidly stirred solution of a sample of $1\left(0.16 \mathrm{~g}, 0.37 \mathrm{mmol} \mathrm{P}, M_{\mathrm{n}}=3,600 \mathrm{~g} \mathrm{~mol}^{-1}, \mathrm{Ð}=\right.$ 2.2) in $\mathrm{CH}_{2} \mathrm{Cl}_{2}(50 \mathrm{~mL}), \mathrm{H}_{2} \mathrm{O}_{2}(20 \%$ in water, $20 \mathrm{~mL})$ was added at room temperature. The reaction was stirred rigorously for $1 \mathrm{~h}$, at which time a ${ }^{31} \mathrm{P}\left\{{ }^{1} \mathrm{H}\right\} \mathrm{NMR}$ spectrum of the reaction mixture was taken and all the starting material had been consumed. The organic layer was taken and the solvent was removed in vacuo to leave a dark red solid. This solid was dried in a vacuum oven for $3 \mathrm{~h}$. Yield $0.14 \mathrm{~g}(87 \%)$.

${ }^{31} \mathrm{P}\left\{{ }^{1} \mathrm{H}\right\}$ NMR $\left(121 \mathrm{MHz}, \mathrm{CDCl}_{3}\right): \delta-18.6(\mathrm{br}, 1 \mathrm{P}),-19.0(\mathrm{br}, 4.7 \mathrm{P}),-19.5(\mathrm{br}, 6.2 \mathrm{P}) ;{ }^{1} \mathrm{H}$ NMR $\left(600 \mathrm{MHz}, \mathrm{CDCl}_{3}\right): \delta 8.09$ (br, 2H, aryl H), 7.62 (br, 4H, aryl H) 7.47 (br, 3H, aryl H) 7.41 (br, $2 \mathrm{H}$, ary; $\mathrm{H}$ ), 3.38 (s, $\mathrm{C} \equiv \mathrm{CH}$ end group), 2.70 (br, $2.5 \mathrm{H},{ }^{\mathrm{Ph}} \mathrm{C}_{\mathrm{ipso}}-\mathrm{CH}_{2}$ ), 1.96 (br, $0.80 \mathrm{H}$, ${ }^{\mathrm{Flu}} \mathrm{CH}_{2}$ ), 1.56 (br, 2.40H), 1.14 (br m, 13H), 1.12-0.95 (br m, 4H), 0.84 (br m, 6H, $\left.\mathrm{CH}_{3}\right), 0.55$ (br, $2 \mathrm{H}$ $\mathrm{CH}_{2}$ ) ${ }^{13} \mathrm{C}\left\{{ }^{1} \mathrm{H}\right\}$ NMR $\left(151 \mathrm{MHz}, \mathrm{CDCl}_{3}\right.$ ): $\delta$ 151.4, (Fluorene aryl C), 144.2 (aryl C), 143.8 (aryl C), 143.0 (aryl C), 142.3 (aryl C), 133.4 (aryl C), 133.1 (aryl C), 132.8 (aryl C), 131.9 (aryl C), 131.2 (aryl C), 130.3 (aryl C), 130.2 (aryl C), 130.2 (aryl C), 130.1 (aryl C), 127.0 (aryl C), 126.5 (aryl C), 124.2 (aryl C), 121.4 (aryl C), 120.5 (aryl C), 120.0 (aryl C), 119.8 (aryl C). $119.0\left(\mathrm{~m}\right.$, aryl C) $104.7\left(\mathrm{P}-\mathrm{C} \equiv C-\mathrm{C}_{\mathrm{Ar}}\right), 101.8\left(\mathrm{P}-\mathrm{C} \equiv C-\mathrm{C}_{\mathrm{Ar}}\right), 89.1\left(\mathrm{br}, \mathrm{P}-C \equiv \mathrm{C}-\mathrm{C}_{\mathrm{Ar}}\right), 87.8(\mathrm{br}), 86.6$ (br, P-C $\left.\equiv \mathrm{C}-\mathrm{C}_{\mathrm{Ar}}\right), 84.2\left(\mathrm{br},{ }^{\mathrm{Flu}} \mathrm{C}_{\mathrm{Ar}}-\mathrm{C} \equiv \mathrm{CH}\right) 82.9\left({ }^{\mathrm{Ph}} \mathrm{C}_{\mathrm{Ar}}-\mathrm{C} \equiv \mathrm{CH}\right), 81.6\left({ }^{\mathrm{Ph}} \mathrm{C}_{\mathrm{Ar}}-\mathrm{C} \equiv \mathrm{CH}\right), 55.5\left({ }^{\mathrm{Flu} C}-\mathrm{CH}_{2}\right)$, $40.0\left(\mathrm{CH}_{2}\right), 34.0\left(\mathrm{CH}_{2}\right) 33.8\left(\mathrm{CH}_{2}\right), 33.6\left(\mathrm{CH}_{2}\right), 31.4\left(\mathrm{CH}_{2}\right), 31.3\left(\mathrm{CH}_{2}\right), 30.6\left(\mathrm{CH}_{2}\right), 30.5\left(\mathrm{CH}_{2}\right)$, 
$30.2\left(\mathrm{CH}_{2}\right), 29.4\left(\mathrm{CH}_{2}\right), 28.9\left(\mathrm{CH}_{2}\right), 23.5\left(\mathrm{CH}_{2}\right), 22.4\left(\mathrm{CH}_{2}\right), 13.86\left(\mathrm{CH}_{3}\right), 13.82\left(\mathrm{CH}_{3}\right) . \mathrm{GPC}(v s$. Polystyrene, THF): $M_{\mathrm{n}}=3,200 \mathrm{~g} \mathrm{~mol}^{-1}, \mathrm{Ð}=1.7$.

\section{General Procedure for Sensing Tests involving polymer 1}

A stock THF solution of $\mathbf{1}(\mathrm{c}=20 \mu \mathrm{M})$ was prepared in a glovebox. Aliquots ( $3 \mathrm{~mL} 60 \mathrm{nmol})$ were taken from this stock solution and $75 \mu \mathrm{L}$ of a EtOH solution $(\mathrm{c}=8.0 \mathrm{mM}, 600 \mathrm{nmol}, 10$ equiv) of metal ion were added to these aliquots outside of the glovebox. Each reaction was swirled initially and left for $10 \mathrm{~min}$ without stirring. The fluorescence spectra were taken after this time using $353 \mathrm{~nm}$ as an excitation wavelength. The metal salts used were $\mathrm{NaNO}_{3}$ $\mathrm{KNO}_{3}, \mathrm{Fe}\left(\mathrm{NO}_{3}\right)_{3} \cdot 9 \mathrm{H}_{2} \mathrm{O}, \mathrm{Ni}\left(\mathrm{NO}_{3}\right)_{2} \cdot 6 \mathrm{H}_{2} \mathrm{O}, \mathrm{Cu}(\mathrm{OAc})_{2}, \mathrm{Y}\left(\mathrm{NO}_{3}\right)_{3} \cdot 6 \mathrm{H}_{2} \mathrm{O}, \mathrm{RuCl}_{3} \cdot \mathrm{xH}_{2} \mathrm{O}[\mathrm{Rh}(\mathrm{cod}) \mathrm{Cl}]_{2}$, $\mathrm{PdCl}_{2}, \mathrm{Pd}\left(\mathrm{PPh}_{3}\right)_{2} \mathrm{Cl}_{2}, \mathrm{Pd}(\mathrm{OAc})_{2}, \mathrm{Pd}\left(\mathrm{PPh}_{3}\right)_{4}, \mathrm{AgNO}_{3}, \mathrm{Cd}\left(\mathrm{NO}_{3}\right)_{2} \cdot 4 \mathrm{H}_{2} \mathrm{O}, \mathrm{Ba}\left(\mathrm{NO}_{3}\right)_{2}, \mathrm{~W}(\mathrm{CO})_{5} \mathrm{MeCN}$, $[\mathrm{Ir}(\mathrm{cod}) \mathrm{Cl}]_{2}, \mathrm{PtCl}_{2}, \mathrm{~K}_{2} \mathrm{PtCl}_{4}, \mathrm{Au}$ (tht)Cl, $\mathrm{HAuCl}_{4} \cdot 3 \mathrm{H}_{2} \mathrm{O}, \mathrm{Hg}_{2}\left(\mathrm{NO}_{3}\right)_{2}, \mathrm{Hg}\left(\mathrm{NO}_{3}\right)_{2} \cdot \mathrm{H}_{2} \mathrm{O}, \mathrm{Pb}\left(\mathrm{NO}_{3}\right)_{2}$, $\mathrm{Bi}\left(\mathrm{NO}_{3}\right)_{3} \cdot 5 \mathrm{H}_{2} \mathrm{O}$. Due to solubility $\mathrm{PdCl}_{2}, \mathrm{Pd}\left(\mathrm{PPh}_{3}\right)_{2} \mathrm{Cl}_{2}, \mathrm{PtCl}_{2}, \mathrm{Au}(\mathrm{tht}) \mathrm{Cl},[\mathrm{Rh}(\mathrm{cod}) \mathrm{Cl}]_{2}$, $\mathrm{RuCl}_{3} \cdot \mathrm{xH}_{2} \mathrm{O},[\mathrm{Ir}(\operatorname{cod}) \mathrm{Cl}]_{2} \mathrm{Pd}\left(\mathrm{PPh}_{3}\right)_{4}$ and $\mathrm{W}(\mathrm{CO})_{5} \mathrm{MeCN}$ were added as THF solutions and $\mathrm{Y}\left(\mathrm{NO}_{3}\right) \cdot 6 \mathrm{H}_{2} \mathrm{O}, \mathrm{Ba}\left(\mathrm{NO}_{3}\right)_{2}$ and $\mathrm{K}_{2} \mathrm{PtCl}_{4}$, were added as aqueous solutions.

\section{Attempted preparation of $1 \cdot A u(I I I)$ polymer}

In a glovebox, THF (10 mL) was added to a vial containing $1(65 \mathrm{mg}, 140 \mu \mathrm{mol})$ and the mixture was stirred at RT until the polymer had dissolved ( $\mathrm{ca} .30 \mathrm{~min}$ ). To this solution was added $\mathrm{HAuCl}_{4} \cdot 3 \mathrm{H}_{2} \mathrm{O}(55 \mathrm{mg}, 140 \mu \mathrm{mol})$, and the mixture was stirred at RT for $20 \mathrm{~min}$. After this time a ${ }^{31} \mathrm{P}\left\{{ }^{1} \mathrm{H}\right\}$ NMR spectrum was recorded which revealed complete consumption of the starting material and the presence of a two new signals at -27 and $-22 \mathrm{ppm}$. The reaction vessel was removed from the glovebox and the solvent was removed. Unfortunately the red solid residue that was isolated could not be dissolved in organic solvents (THF, DCM, DMSO, toluene etc). Yield $116 \mathrm{mg}$ (99\%). Identical ${ }^{31} \mathrm{P}\left\{{ }^{1} \mathrm{H}\right\}$ NMR spectra were obtained when $70 \mu \mathrm{mol} \mathrm{HAuCl}_{4} \cdot 3 \mathrm{H}_{2} \mathrm{O}$ were employed.

\section{Preparation of 1 $(\mathrm{AuCl})_{\mathrm{n}}$}

In a glovebox, THF (10 mL) was added to a vial containing polymer $1(60 \mathrm{mg}, 140 \mu \mathrm{mol}$ P) and the mixture was stirred at RT until the polymer had dissolved ( $c a .30 \mathrm{~min}$ ). To the solution was added Au(tht)Cl (49 mg, $150 \mu \mathrm{mol}$ ) and the solution was stirred at RT for 30 min. After this time a ${ }^{31} \mathrm{P}\{1 \mathrm{H}\}$ NMR spectrum was recorded which revealed complete consumption of the starting material and the presence of a two new signals at $-28.0 \mathrm{ppm}$ and $-28.2 \mathrm{ppm}$. The reaction vessel was removed from the glovebox and the solvent was removed under reduced pressure, leaving an orange residue. To this residue was added THF (1 mL) and the polymer was precipitated into degassed methanol $(25 \mathrm{~mL})$. The resulting orange solid was isolated and dried under reduced pressure at RT for $2 \mathrm{~h}$. Yield = $92 \mathrm{mg}(99 \%)$.

${ }^{31} \mathrm{P}\left\{{ }^{1} \mathrm{H}\right\}$ NMR $\left(162 \mathrm{MHz}, \mathrm{CDCl}_{3}\right) \delta-28.0(\mathrm{br}),-28.2(\mathrm{br}) ;{ }^{1} \mathrm{H}$ NMR $\left(400 \mathrm{MHz}, \mathrm{CDCl}_{3}\right): \delta 8.25-$ 7.97 (br, 2H, aryl H), 7.80-7.51 (br, 3H, aryl H), 7.49-7.30 (br, 2H, aryl H) 3.58-3.25 (br, $1 \mathrm{H}$, $\mathrm{CH}_{2}$ ), 2.79-2.50 (br, 2H, CH $\mathrm{CH}_{2}$ ) 2.31-1.78 (br, $2 \mathrm{H}, \mathrm{CH}_{2}$ ), 1.68-1.43 (br, 2H, $\mathrm{CH}_{2}$ ) 1.36-0.94 (br, $12 \mathrm{H}, \mathrm{CH}_{2}+\mathrm{CH}_{3}$ ), 0.95-0.33 (br, $\left.10 \mathrm{H}, \mathrm{CH}_{2}+\mathrm{CH}_{3}\right) ;{ }^{13} \mathrm{C}\left\{{ }^{1} \mathrm{H}\right\}$ NMR $\left(151 \mathrm{MHz}, \mathrm{CDCl}_{3}\right): \delta 151.8-151.3$ (Fluorene aryl C), 144.3 (aryl C), 143.9 (aryl C), 143.3 (aryl C), 142.5 (aryl C), 133.8-132.7 (m, aryl C), 132.0 (aryl C), 129.9-129.3 (m, aryl C), 127.0 (aryl C), 122.0-121.3 (m, aryl C), 120.7 (aryl C), 119.5-118.8 (m, aryl C), 107.9-105.9 (br, $\left.\mathrm{P}-\mathrm{C} \equiv C-\mathrm{C}_{\mathrm{Ar}}\right), 83.2\left(\mathrm{P}-\mathrm{C} \equiv \mathrm{C}-\mathrm{C}_{\mathrm{Ar}}\right.$ ), 81.7 $(\mathrm{C} \equiv \mathrm{CH}), 55.7\left(\mathrm{Flu} C-\mathrm{CH}_{2}\right), 40.1\left(\mathrm{CH}_{2}\right), 34.1\left(\mathrm{CH}_{2}\right), 33.7\left(\mathrm{CH}_{2}\right), 31.6\left(\mathrm{CH}_{2}\right), 30.7\left(\mathrm{CH}_{2}\right), 30.3\left(\mathrm{CH}_{2}\right)$, $29.6\left(\mathrm{CH}_{2}\right), 29.1\left(\mathrm{CH}_{2}\right), 23.7\left(\mathrm{CH}_{2}\right), 22.5\left(\mathrm{CH}_{2}\right), 14.0\left(\mathrm{CH}_{3}\right)$. GPC (vs. Polystyrene, THF): $M_{\mathrm{n}}=$ $5,000 \mathrm{~g} \mathrm{~mol}^{-1}, Ð=3.1$. 


\section{Preparation of $1 \cdot[\mathrm{Rh}(\operatorname{cod}) \mathrm{Cl}]_{2}$}

In a glovebox, $\mathrm{CD}_{2} \mathrm{Cl}_{2}(0.5 \mathrm{~mL})$ was added to a vial containing PPYP 1 (10 mg, $22 \mu \mathrm{mol}$ P: For 1: $x=1, y=1 ; \mathrm{M}_{\mathrm{n}}=3,200 \mathrm{~g} \mathrm{~mol}^{-1}, \mathrm{Ð}=1.7$ ) and the mixture was stirred at RT until the polymer had dissolved (ca. $3 \mathrm{~h}$ ). The ${ }^{31} \mathrm{P}$ NMR spectrum showed resonances at $-60.2(\mathrm{br}, 3$ P), -60.5 (br, 5 P) and $-60.9 \mathrm{ppm}(\mathrm{br}, 2 \mathrm{P})$. To the solution was added a solution of $[\mathrm{Rh}(\mathrm{cod}) \mathrm{Cl}]_{2}(6 \mathrm{mg}, 12 \mu \mathrm{mol})$ in $\mathrm{CD}_{2} \mathrm{Cl}_{2}(0.5 \mathrm{~mL})$. The resultant reaction mixture was transferred to an NMR tube and ${ }^{31} \mathrm{P}$ and ${ }^{1} \mathrm{H}$ NMR spectra were recorded. Irradiation of the sample under a UV lamp revealed no emission. After a few hours, the sample started precipitating from solution (possibly due to crosslinking) precluding GPC analysis.

31P NMR (162 MHz, $\mathrm{CD}_{2} \mathrm{Cl}_{2}$ ): $\delta-17.5\left(\mathrm{~d},{ }^{1} J_{\mathrm{Rh}-\mathrm{P}}=163 \mathrm{~Hz}, 2 \mathrm{P}\right),-17.8\left(\mathrm{~d},{ }^{1} J_{\mathrm{Rh}-\mathrm{P}}=154 \mathrm{~Hz}, 5\right.$ P), $-17.2\left(\mathrm{~d},{ }^{1} J_{\mathrm{Rh}-\mathrm{P}}=168 \mathrm{~Hz}, 3 \mathrm{P}\right) ;{ }^{1} \mathrm{H}$ NMR $\left(400 \mathrm{MHz}, \mathrm{CD}_{2} \mathrm{Cl}_{2}\right.$ ): $\delta 8.31-8.17(\mathrm{br}, 2 \mathrm{H}$, aryl H), 7.76-7.66 (br, 1H, aryl-H), 7.63-7.44 (br, 5H, aryl-H), 7.41-7.29 (br, 1H, aryl-H), 5.62 (br, 2H, cod-CH), 4.00-3.81 (br, 2H, cod-CH), 2.72 (br, 2H, Hex- $\mathrm{CH}_{2}$ ), 2.64-2.39 (br, 6H, cod$\mathrm{CH}_{2}+\mathrm{Hex}-\mathrm{CH}_{2}$ ), 2.29-2.13 (br, 4H, cod- $\mathrm{CH}_{2}$ ), 1.98 (br, 2H, Hex- $\mathrm{CH}_{2}$ ), 1.57 (br, 2H, Hex- $\mathrm{CH}_{2}$ ), 1.39-0.42 (br m, integral > expected $18 \mathrm{H}, \mathrm{Hex}-\mathrm{CH}_{2}+\mathrm{CH}_{3}+$ unidentified aliphatic impurities).

\section{Air Oxidation of 1}

PPYP 1 (10 mg) was dissolved in THF (1 mL) and the resultant solution was exposed to air and evaluated by ${ }^{31} \mathrm{P}$ NMR spectroscopy. Results [time $(\mathrm{h}), \% \mathbf{1} \cdot(0)_{\mathrm{n}}$ ]: $1 \mathrm{~h}, 0 \% ; 2 \mathrm{~h}, 12 \% ; 3 \mathrm{~h}$, $17 \% ; 72 \mathrm{~h}, 67 \%$.

\section{Preparation of 2}

Under $\mathrm{N}_{2}$, a Schlenk flask was charged with diphenylchlorophosphine $(1.82 \mathrm{~g}, 1.5 \mathrm{~mL}, 8.25$ mmol), nickel (II) acetylacetonate (52.8 mg, $206.5 \mu \mathrm{mol}), 2,7$-diethynyl-9,9-dimethyl-9Hfluorene $(1 \mathrm{~g}, 4.13 \mathrm{mmol})$ and toluene $(15 \mathrm{~mL})$. Triethylamine $(2.5 \mathrm{~g}, 3.4 \mathrm{~mL}, 24.8 \mathrm{mmol})$ was subsequently added to the reaction mixture. The deep red reaction mixture was stirred vigorously at $85{ }^{\circ} \mathrm{C}$ for $12 \mathrm{~h}$. After this time, an ${ }^{31} \mathrm{P}\left\{{ }^{1} \mathrm{H}\right\}$ NMR spectrum of the reaction mixture was taken. This spectrum showed a single signal at $-33 \mathrm{ppm}$. The volatiles were removed from the reaction mixture under reduced pressure to leave a brown coloured solid residue. To this mixture was added dichloromethane $(30 \mathrm{~mL})$ and deoxygenated water under nitrogen. The organic fraction was taken and solvent removed under reduced pressure. The resulting brown solid was washed with ethanol (50 $\mathrm{mL})$ to leave a pale brown free flowing powder. Yield: $1.91 \mathrm{~g}(76 \%)$. A crystal suitable for X-ray analysis was grown from a saturated 1:60 toluene and diethyl ether solution.

${ }^{31} \mathrm{P}\left\{{ }^{1} \mathrm{H}\right\}$ NMR $\left(162 \mathrm{MHz}, \mathrm{CDCl}_{3}\right): \delta=-33.1(\mathrm{~s}) .{ }^{1} \mathrm{H}$ NMR $\left(400 \mathrm{MHz}, \mathrm{CDCl}_{3}\right): \delta=7.75(\mathrm{~s}, 2 \mathrm{H}$, $\left.\mathrm{C}_{\mathrm{Ar}}-\mathrm{H}\right), 7.73\left(\mathrm{~s}, 4 \mathrm{H}, \mathrm{C}_{\mathrm{Ar}}-\mathrm{H}\right), 7.71\left(\mathrm{~s}, 3 \mathrm{H}, \mathrm{C}_{\mathrm{Ar}}-\mathrm{H}\right), 7.69\left(\mathrm{~s}, 1 \mathrm{H}, \mathrm{C}_{\mathrm{Ar}}-\mathrm{H}\right), 7.62\left(\mathrm{~s}, 2 \mathrm{H}, \mathrm{C}_{\mathrm{Ar}}-\mathrm{H}\right), 7.58-7.56$ $\left(\mathrm{dd}, 2 \mathrm{H}, J=8\right.$ and $\left.2, \mathrm{C}_{\mathrm{Ar}}-\mathrm{H}\right), 7.40\left(\mathrm{~m}, 12 \mathrm{H}, \mathrm{C}_{\mathrm{Ar}}-\mathrm{H}\right), 1.52\left(\mathrm{~s}, 6 \mathrm{H}, \mathrm{CH}_{3}\right) \cdot{ }^{13} \mathrm{C}\left\{{ }^{1} \mathrm{H}\right\} \mathrm{NMR}(101 \mathrm{MHz}$, $\left.\mathrm{CDCl}_{3}\right): \delta=153.9\left(\mathrm{C}_{\mathrm{Ar}}\right), 139.1\left(\mathrm{C}_{\mathrm{Ar}}\right), 136.3(\mathrm{~d}, J=6.1 \mathrm{~Hz}), 132.7\left(\mathrm{C}_{\mathrm{Ar}}\right), 132.5\left(\mathrm{C}_{\mathrm{Ar}}\right), 131.2\left(\mathrm{C}_{\mathrm{Ar}}\right)$, $129.0\left(\mathrm{C}_{\mathrm{Ar}}\right), 128.7\left(\mathrm{C}_{\mathrm{Ar}}\right), 128.6\left(\mathrm{C}_{\mathrm{Ar}}\right), 126.2\left(\mathrm{C}_{\mathrm{Ar}}\right), 121.8\left(\mathrm{C}_{\mathrm{Ar}}\right), 120.3\left(\mathrm{C}_{\mathrm{Ar}}\right), 108.4(\mathrm{~d}, J=4.2 \mathrm{~Hz}, \mathrm{P}-$ $\mathrm{C} \equiv C), 86.2(\mathrm{~d}, J=6.5 \mathrm{~Hz}, \mathrm{P}-C \equiv \mathrm{C}), 47.0\left(C-\mathrm{CH}_{3}\right), 26.9\left(\mathrm{CH}_{3}\right)$. Elem. Anal. (\%) calcd for $\mathrm{C}_{43} \mathrm{H}_{32} \mathrm{P}_{2}$ : C 84.27, H 5.28; found C 76.41, H 5.33. HRMS 610.197 [M]+

\section{Preparation of $2 \cdot(0)_{2}$}

A flask was charged with 2 (0.131, $0.22 \mathrm{mmol})$ and dissolved in dichloromethane $(20 \mathrm{~mL})$. Hydrogen peroxide ( $50 \%$ in water, $30 \mathrm{~mL}$ ) was added to the solution at RT. The reaction was stirred vigorously for $1 \mathrm{hr}$. The reaction mixture was washed with water and the compound was extracted with dichloromethane. Yield: $0.104 \mathrm{~g}$ (74\%). Crystals Suitable for $\mathrm{x}$-ray analysis were grown from dichloromethane. 
${ }^{31} \mathrm{P}\left\{{ }^{1} \mathrm{H}\right\}$ NMR $\left(162 \mathrm{MHz}, \mathrm{CDCl}_{3}\right): \delta=7.7$ (s). ${ }^{1} \mathrm{H}$ NMR $\left(400 \mathrm{MHz}, \mathrm{CDCl}_{3}\right): \delta=7.97-7.92(\mathrm{br} \mathrm{m}$, $\left.8 \mathrm{H}, \mathrm{C}_{\mathrm{Ar}}-\mathrm{H}\right), 7.75\left(\mathrm{~s}, 1 \mathrm{H}, \mathrm{C}_{\mathrm{Ar}}-\mathrm{H}\right), 7.73\left(\mathrm{~s}, 1 \mathrm{H}, \mathrm{C}_{\mathrm{Ar}}-\mathrm{H}\right), 7.67\left(\mathrm{~s}, 2 \mathrm{H}, \mathrm{C}_{\mathrm{Ar}}-\mathrm{H}\right), 7.63\left(\mathrm{~s}, 1 \mathrm{H}, \mathrm{C}_{\mathrm{Ar}}-\mathrm{H}\right), 7.61$ (s, $\left.1 \mathrm{H}, \mathrm{C}_{\mathrm{Ar}}-\mathrm{H}\right), 1.50\left(\mathrm{~s}, 6 \mathrm{H}, \mathrm{CH}_{3}\right){ }^{13} \mathrm{C}\left\{{ }^{1} \mathrm{H}\right\}$ NMR $\left(101 \mathrm{MHz}, \mathrm{CDCl}_{3}\right): \delta=154.2\left(\mathrm{C}_{\mathrm{Ar}}\right), 133.5\left(\mathrm{C}_{\mathrm{Ar}}\right)$, $132.4(\mathrm{~d}, J=3 \mathrm{~Hz}), 132.1\left(\mathrm{C}_{\mathrm{Ar}}\right), 131.1\left(\mathrm{C}_{\mathrm{Ar}}\right), 131.0\left(\mathrm{C}_{\mathrm{Ar}}\right), 128.8\left(\mathrm{C}_{\mathrm{Ar}}\right), 128.7\left(\mathrm{C}_{\mathrm{Ar}}\right), 127.0\left(\mathrm{C}_{\mathrm{Ar}}\right)$, $121.0\left(\mathrm{C}_{\mathrm{Ar}}\right), 119.3\left(\mathrm{C}_{\mathrm{Ar}}\right), 106.1(\mathrm{~d}, J=30 \mathrm{~Hz}, \mathrm{P}-\mathrm{C} \equiv C), 83.4(\mathrm{~d}, J=170 \mathrm{~Hz}, \mathrm{P}-C \equiv \mathrm{C}), 47.2\left(C-\mathrm{CH}_{3}\right)$, $26.7\left(\mathrm{CH}_{3}\right)$. Elem. Anal. (\%) calcd for $\mathrm{C}_{43} \mathrm{H}_{32} \mathrm{P}_{2} \mathrm{O}_{2}$ : C 80.26, H 5.02; found $\mathrm{C} 76.15$, H 5.04 . HRMS $642.187[\mathrm{M}]^{+}$

\section{Preparation of $2 \cdot(\mathrm{AuCl})_{2}$}

A Schlenk flask was charged with Compound 2 (100 mg, $0.16 \mathrm{mmol})$, Au(tht)Cl (108 mg, $0.33 \mathrm{mmol})$ and dichloromethane $(10 \mathrm{~mL})$ the reaction mixture was stirred for 20 minutes. A ${ }^{31} \mathrm{P}\left\{{ }_{1} \mathrm{H}\right\}$ NMR spectrum was taken of an aliquot of the reaction mixture. The spectrum revealed a new signal at $3.5 \mathrm{ppm}$ and complete consumption of the starting material $(-33.1$ ppm). Volatiles were removed under reduced pressure. Crystals suitable for x-ray analysis were grown from a saturated dichloromethane solution. Yield: $139 \mathrm{mg}(81 \%)$

${ }^{31} \mathrm{P}\left\{{ }^{1} \mathrm{H}\right\}$ NMR $\left(162 \mathrm{MHz}, \mathrm{CDCl}_{3}\right): \delta=3.5(\mathrm{~s}) .{ }^{1} \mathrm{H}$ NMR $\left(400 \mathrm{MHz}, \mathrm{CDCl}_{3}\right): \delta=7.92-7.85$ (ddt, $8 \mathrm{H}, J=9.5,3$, and $\left.2, \mathrm{C}_{\mathrm{Ar}}-\mathrm{H}\right), 7.81\left(\mathrm{~s}, 1 \mathrm{H}, \mathrm{C}_{\mathrm{Ar}}-\mathrm{H}\right), 7.79\left(\mathrm{~s}, 1 \mathrm{H}, \mathrm{C}_{\mathrm{Ar}}-\mathrm{H}\right), 7.70\left(\mathrm{~s}, 2 \mathrm{H}, \mathrm{C}_{\mathrm{Ar}}-\mathrm{H}\right), 7.67-$ 7.63 (dd, $2 \mathrm{H}, J=8$ and 2, $\left.\mathrm{C}_{\mathrm{Ar}}-\mathrm{H}\right), 7.56\left(\mathrm{~m}, 12 \mathrm{H}, \mathrm{C}_{\mathrm{Ar}}-\mathrm{H}\right), 1.55\left(\mathrm{~s}, 6 \mathrm{H}, \mathrm{CH}_{3}\right)$. Elem. Anal. (\%) calcd for $\mathrm{C}_{43} \mathrm{H}_{32} \mathrm{P}_{2} \mathrm{Au}_{2} \mathrm{Cl}_{2}$ : C 48.02, H 3.00; found C 47.42, H 2.99 .

\section{Preparation of $2 \cdot[\mathrm{Rh}(\mathrm{cod}) \mathrm{Cl}]_{2}$}

In the glovebox, a glass vial was charged with compound 2 (40 $\left.\mathrm{mg}, 8 \cdot 10^{-2} \mathrm{mmol}\right)$, $[\mathrm{Rh}(\mathrm{cod}) \mathrm{Cl}]_{2}\left(49.5 \mathrm{mg}, 16 \cdot 10^{-2} \mathrm{mmol}\right)$ and $\mathrm{CD}_{2} \mathrm{Cl}_{2}(1.0 \mathrm{~mL})$. A clear brown-yellowish solution formed almost immediately. The reaction mixture was stirred for $20 \mathrm{~min}$ at room temperature. Thereafter it was transferred into a 7" NMR tube, the NMR tube was taken out of the glovebox and flame sealed. Analysis by ${ }^{1} \mathrm{H},{ }^{31} \mathrm{P}$ and ${ }^{31} \mathrm{P}\left\{{ }^{1} \mathrm{H}\right\}$ NMR spectroscopy revealed that the signal assigned to 3 had been entirely consumed and replaced by a doublet resonance assigned to $3 \cdot[\mathrm{Rh}(\mathrm{cod}) \mathrm{Cl}]_{2}$. Analysis of the ${ }^{1} \mathrm{H}$ NMR spectrum suggested that, in addition to $3 \cdot[\mathrm{Rh}(\mathrm{cod}) \mathrm{Cl}]_{2}$, the sample contained $[\mathrm{Rh}(\mathrm{cod}) \mathrm{Cl}]_{2}(8 \mathrm{~mol} \%)$ and free COD (14 mol\%). The sample showed no change after standing for $24 \mathrm{~h}$ at room temperature in the dark. Attempts to obtain single crystals have, thus far, proven unsuccessful.

${ }^{31} \mathrm{P}\left\{{ }^{1} \mathrm{H}\right\}$ NMR $\left(162 \mathrm{MHz}, \mathrm{CD}_{2} \mathrm{Cl}_{2}\right): \delta=9.7\left(\mathrm{~d},{ }^{1} J_{\mathrm{P}-\mathrm{Rh}}=156 \mathrm{~Hz}\right) ;{ }^{1} \mathrm{H}$ NMR $\left(400 \mathrm{MHz}, \mathrm{CD}_{2} \mathrm{Cl}_{2}\right): \delta=$ 7.99 (br m, 8H, $\left.\mathrm{C}_{\mathrm{Ar}}-H\right), 7.73\left(\mathrm{~m}, 2 \mathrm{H}, \mathrm{C}_{\mathrm{Ar}}-H\right), 7.58\left(\mathrm{~m}, 2 \mathrm{H}, \mathrm{C}_{\mathrm{Ar}}-H\right), 7.54$ (dd, $2 \mathrm{H}, J=8$ and $2 \mathrm{~Hz}$, $\mathrm{C}_{\mathrm{Ar}}-\mathrm{H}$ ), 7.47 (br m, 12H, $\mathrm{C}_{\mathrm{Ar}}-\mathrm{H}$ ), $5.53(\mathrm{~m}, 4 \mathrm{H}, \operatorname{cod}-\mathrm{CH}), 3.83(\mathrm{~m}, 4 \mathrm{H}, \operatorname{cod}-\mathrm{CH}), 2.48(\mathrm{~m}, 8 \mathrm{H}, \mathrm{cod}-$ $\left.\mathrm{CH}_{2}\right), 2.16\left(\mathrm{~m}, 8 \mathrm{H}, \mathrm{cod}-\mathrm{CH}_{2}\right), 1.47\left(\mathrm{~s}, 6 \mathrm{H}, \mathrm{CH}_{3}\right)$.

\section{Titration of 2 with $\mathrm{Au}(\mathrm{tht}) \mathrm{Cl}$}

Model compound $2(0.400 \mathrm{~g}, 0.652 \mathrm{mmol})$ was dissolved in THF $(10.0 \mathrm{~mL}) .13$ aliquots of this solution ( $500 \mu \mathrm{l}$ each) were placed in 13 different vials. To each vial were added 0.00 3.00 equiv of $\mathrm{Au}$ (tht) $\mathrm{Cl}$ in form of a $0.040 \mathrm{M} \mathrm{Au}(\mathrm{tht}) \mathrm{Cl}(262.5 \mathrm{mg})$ solution in THF (20.0 mL) in 0.25 equiv steps, i.e. 0.00 eq. to the first vial, 0.25 equiv to the second, 0.50 equiv to the third, and so on, and each vial was thereafter filled up with THF to the volume of $2.9 \mathrm{~mL}$. From these solutions a $10 \mu \mathrm{L}$ aliquot was removed and diluted to $25 \mathrm{~mL}([2]=4.5 \mu \mathrm{M})$ and their emission spectra $\left(\lambda_{\text {ex }}=353 \mathrm{~nm}\right)$ were recorded. The reaction mixtures in the vials were then allowed to react at room temperature for $10 \mathrm{~min}$. After $10 \mathrm{~min}$ a ${ }^{31} \mathrm{P}\left\{{ }^{1} \mathrm{H}\right\} \mathrm{NMR}$ spectrum of an aliquot $(500 \mu \mathrm{L})$ of each of these samples was also recorded.

The identical experiment was also performed by successively adding 0.25 molar equivalents of $\mathrm{Au}$ (tht) $\mathrm{Cl}$ to the same solution of $\mathbf{2}$ in THF. The results were virtually identical, however, the additional manipulations of the same solution let to the formation of small amounts of the oxide $2 \cdot 0$. 


\section{Titration of 2 with $\left[\mathrm{Rh}(\operatorname{cod}) \mathrm{Cl}_{2}\right.$}

Model compound $2(0.150 \mathrm{~g}, 0.246 \mathrm{mmol})$ was dissolved in THF $(7.5 \mathrm{~mL}) .13$ aliquots of this solution $(500 \mu \mathrm{l}$ each) were placed in 13 different vials. To each vial were added $0.00-3.00$ equiv of $[\mathrm{Rh}(\operatorname{cod}) \mathrm{Cl}]$ in the form of a $0.041 \mathrm{M}[\mathrm{Rh}(\operatorname{cod}) \mathrm{Cl}]_{2}(90.8 \mathrm{mg})$ solution in THF $(9.00$ $\mathrm{mL}$ ) in 0.25 equiv steps, i.e. 0.00 eq. to the first vial, 0.25 equiv to the second, 0.50 equiv to the third, and so on, and each vial was thereafter filled up with THF to the volume of $1.7 \mathrm{~mL}$. From these solutions a $10 \mu \mathrm{L}$ aliquot was removed and diluted to $25 \mathrm{~mL}([2]=3.8 \mu \mathrm{M}$ ) (with respect to the amount of the model compound used) using $25 \mathrm{~mL}$ volumetric flasks, and emission spectra $\left(\lambda_{\mathrm{ex}}=350 \mathrm{~nm}\right)$ were recorded. The reaction mixtures in the vials were then allowed to react at room temperature for $10 \mathrm{~min}$. After $10 \mathrm{~min}$ a ${ }^{31} \mathrm{P}\left\{{ }^{1} \mathrm{H}\right\} \mathrm{NMR}$ spectrum of an aliquot $(500 \mu \mathrm{l})$ of each of these samples was also recorded.

The identical experiment was also performed by successively adding 0.25 molar equivalents of $[\mathrm{Rh}(\operatorname{cod}) \mathrm{Cl}]$ in the form $[\mathrm{Rh}(\operatorname{cod}) \mathrm{Cl}]_{2}$ to the same solution of 2 in THF. The results were virtually identical, however, the additional manipulations of the same solution let to the formation of small amounts of the oxide $\mathbf{2} \cdot 0$.

\section{Variable Temperature NMR Spectroscopic Experiment [2 + Au(tht)Cl]}

An NMR tube containing model compound 2 and (tht) $\mathrm{AuCl}$ ( 1 equiv) in THF solution was cooled to $-90^{\circ} \mathrm{C} .{ }^{31} \mathrm{P}$ NMR spectra were recorded in $\sim 10^{\circ} \mathrm{C}$ increments. The broad signal observed at $-12 \mathrm{ppm}$ at room temperature coalesces and at least four distinct resonances [14 (major), 2 (major), -11 (minor) and $-12 \mathrm{ppm}$ (minor)] are observed at $-90 \cdot \mathrm{C}$. These data are consistent with two or more species. Comparison of the major signal at $14 \mathrm{ppm}$ to the chemical shifts of $2 \cdot(\mathrm{AuCl})_{2}(\delta=3.5)$ and $2(\delta=-33)$ is inconsistent with signals expected for asymmetric $2 \cdot \mathrm{AuCl}$ (should have one signal at ca. 3.5 and one signal at ca. -33 $\mathrm{ppm})$. Therefore, we conclude that more complex intermediates are present whose elucidation will be subject of future investigations.

\section{Spectra}

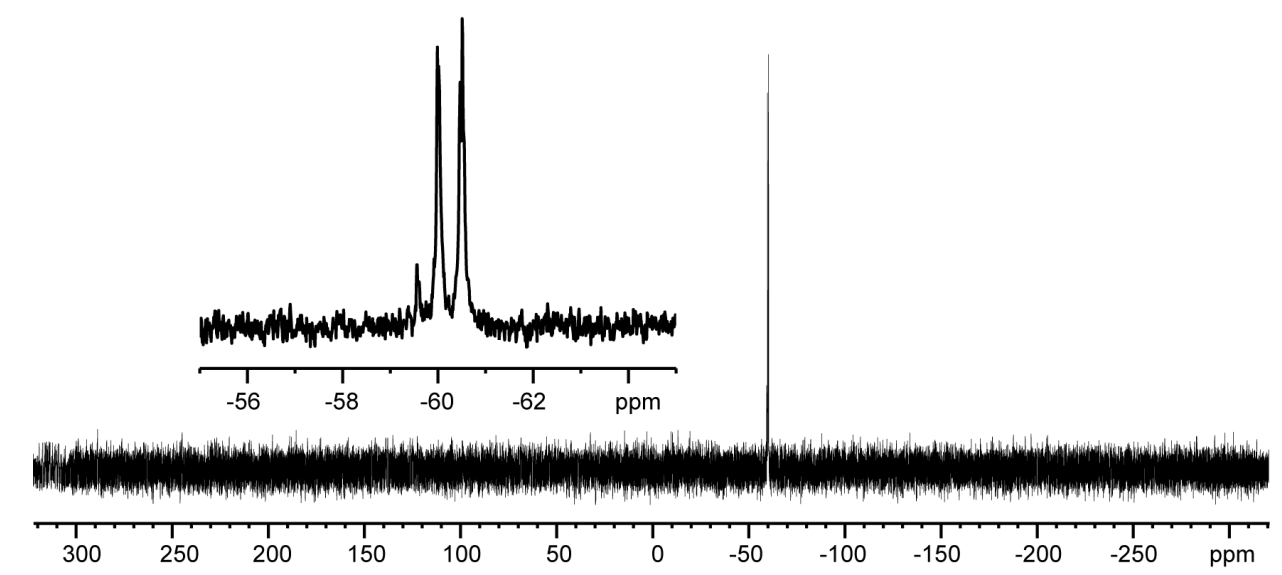

Figure S1. ${ }^{31} \mathrm{P}\left\{{ }^{1} \mathrm{H}\right\}$ NMR spectrum $\left(121 \mathrm{MHz}, \mathrm{CDCl}_{3}\right)$ of $\mathbf{1}$. 


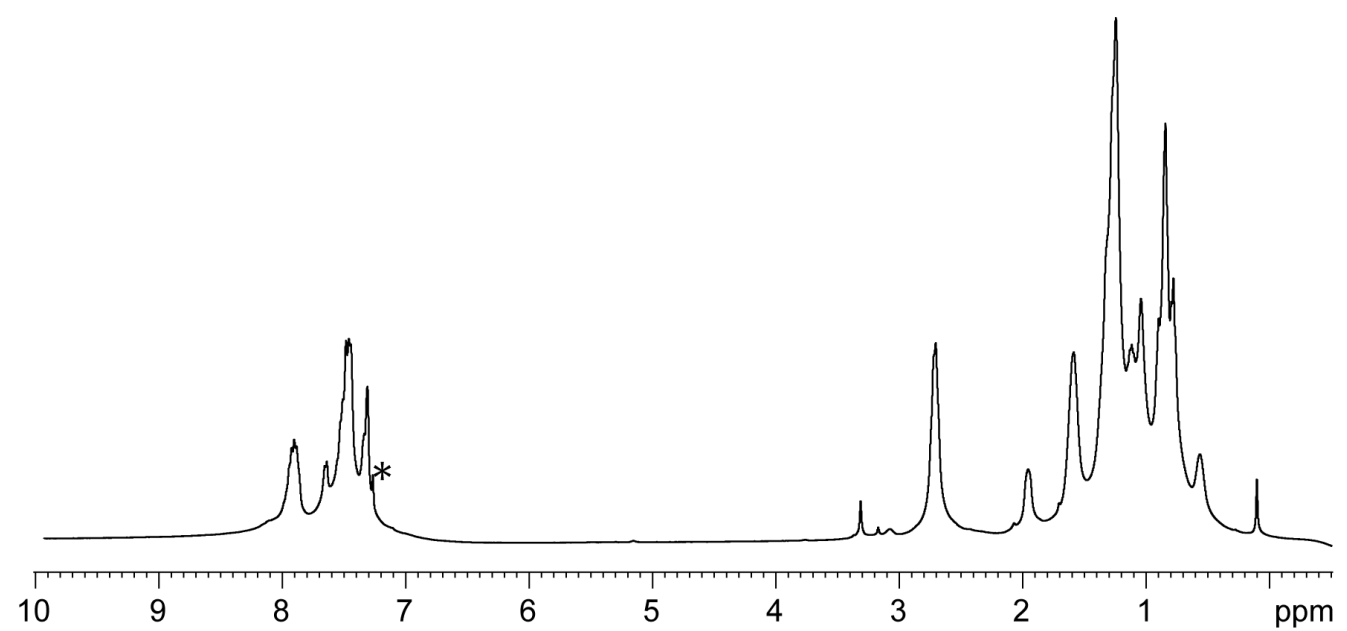

Figure S2. ${ }^{1} \mathrm{H}$ NMR spectrum $\left(400 \mathrm{MHz}, \mathrm{CDCl}_{3}\right)$ of $\mathbf{1} .{ }^{*}=\mathrm{CHCl}_{3}$.

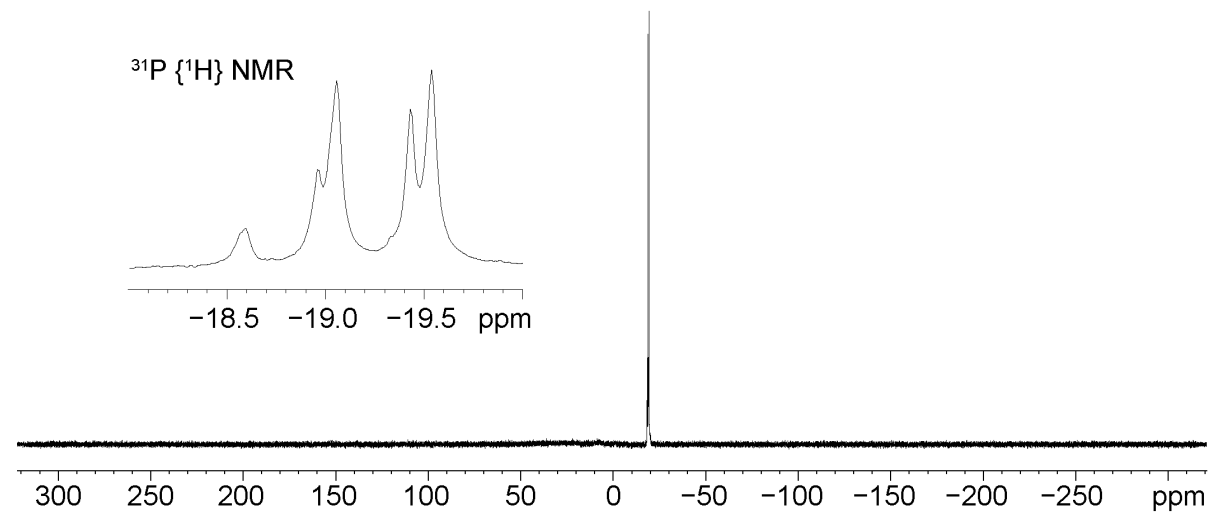

Figure S3. ${ }^{31} \mathrm{P}\left\{{ }^{1} \mathrm{H}\right\}$ NMR spectrum $\left(121 \mathrm{MHz}, \mathrm{CDCl}_{3}\right)$ of $\mathbf{1} \cdot(0)_{n}$.

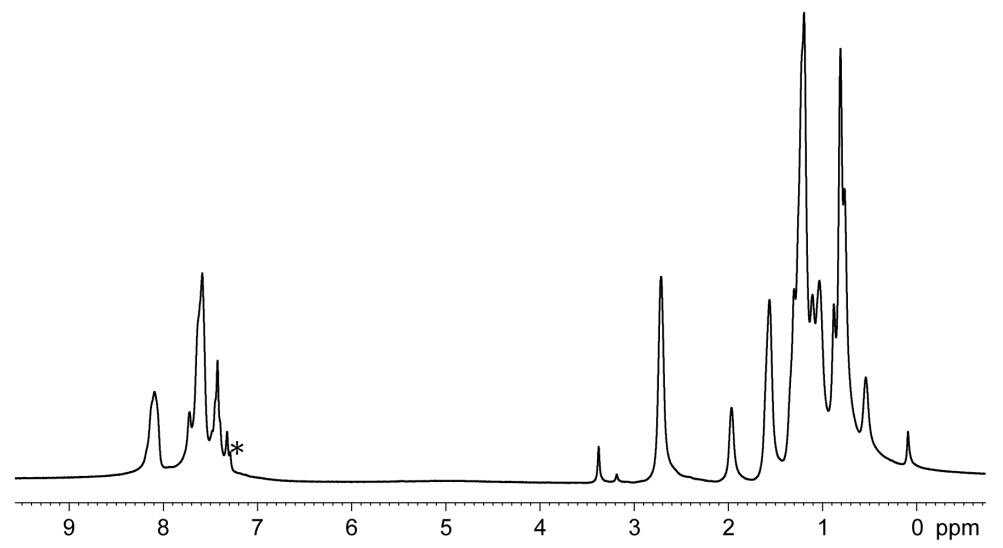

Figure S4. ${ }^{1} \mathrm{H} \mathrm{NMR} \mathrm{spectrum}\left(600 \mathrm{MHz}, \mathrm{CDCl}_{3}\right)$ of $\mathbf{1} \cdot(0)_{n} *{ }^{*}=\mathrm{CHCl}_{3}$. 


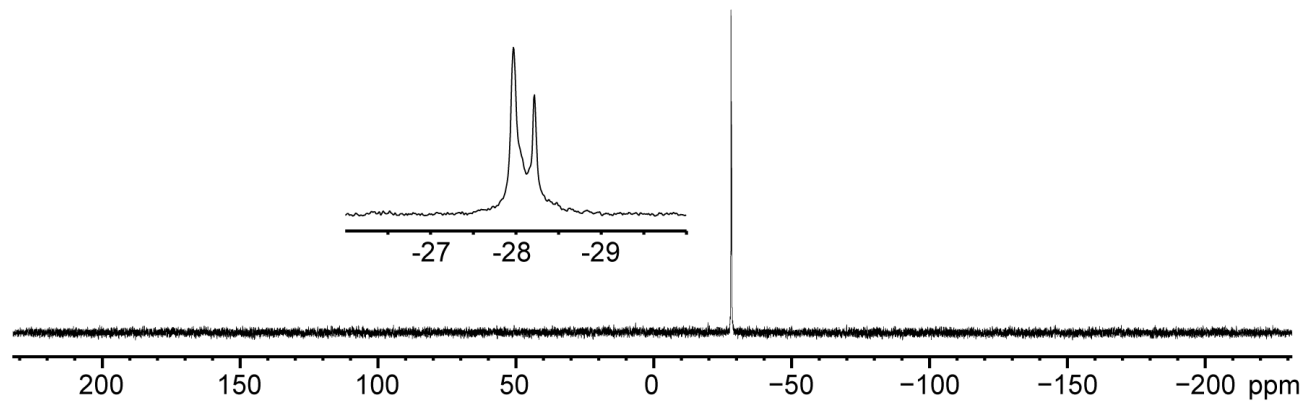

Figure S5. ${ }^{31} \mathrm{P}\left\{{ }^{1} \mathrm{H}\right\}$ NMR spectrum $\left(162 \mathrm{MHz}, \mathrm{CDCl}_{3}\right)$ of $\mathbf{1} \cdot(\mathrm{AuCl})_{n}$.

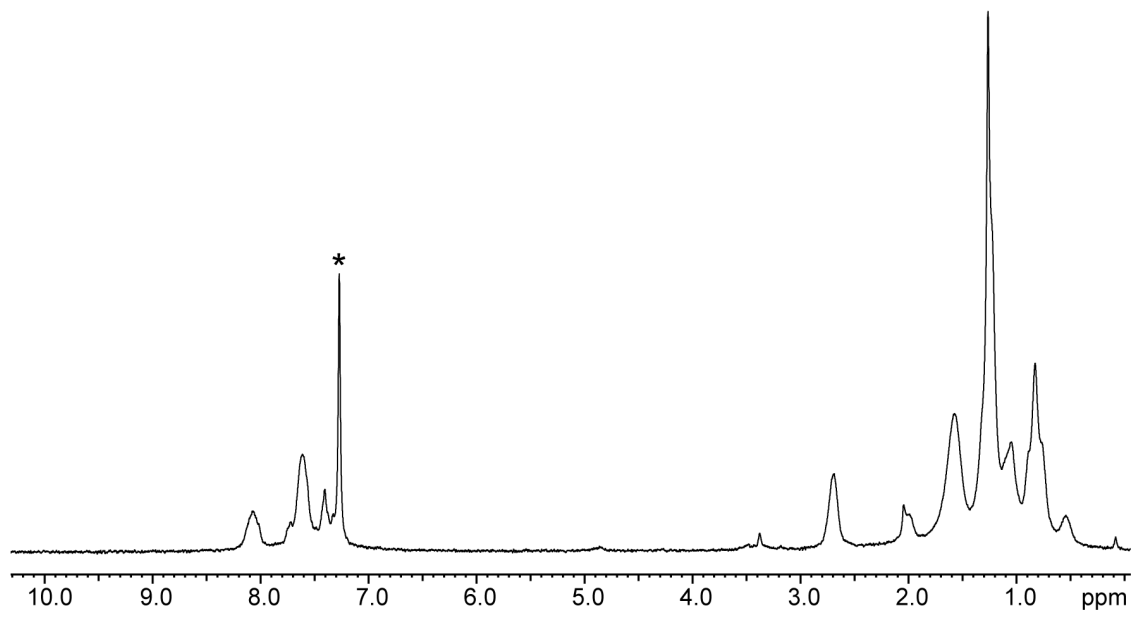

Figure S6. ${ }^{1} \mathrm{H}$ NMR spectrum $\left(400 \mathrm{MHz}, \mathrm{CDCl}_{3}\right)$ of $\mathbf{1} \cdot(\mathrm{AuCl})_{n} \cdot{ }^{*}=\mathrm{CHCl}_{3}$.
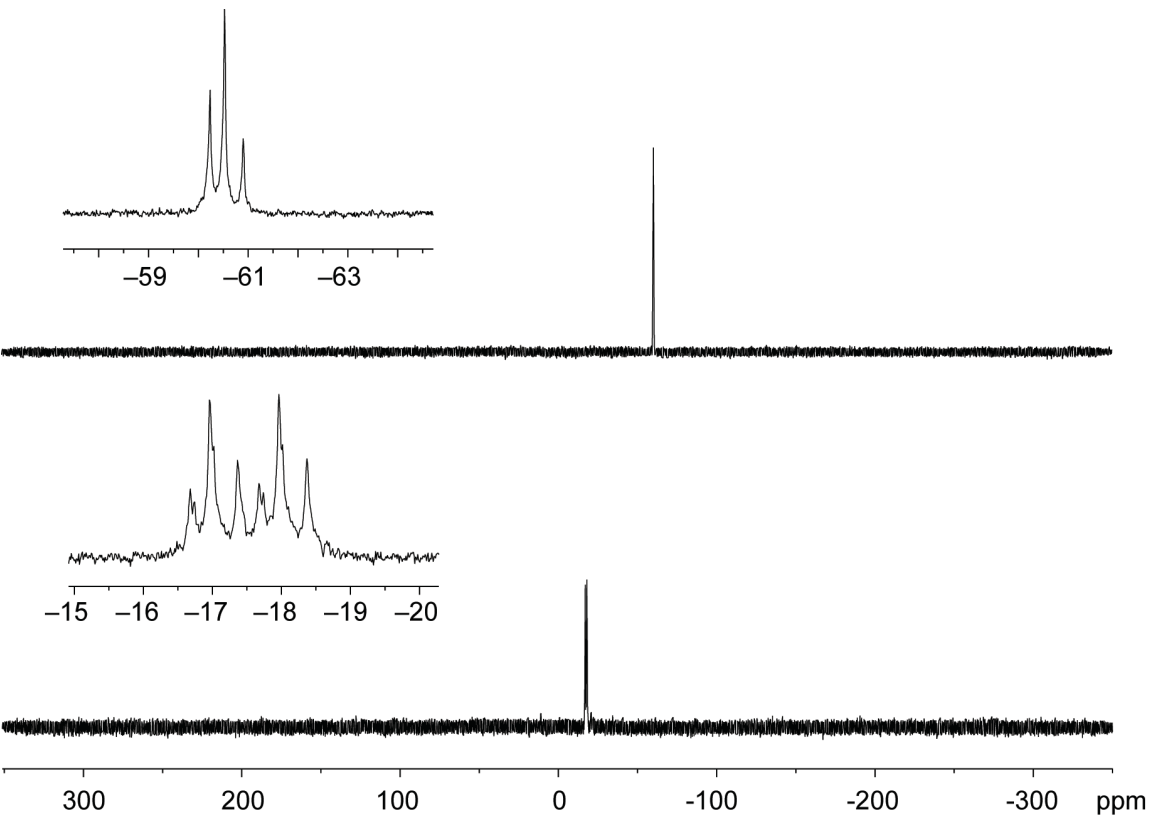

Figure S7. ${ }^{31} \mathrm{P}\left\{{ }^{1} \mathrm{H}\right\}$ NMR spectra (162 $\mathrm{MHz}, \mathrm{CD}_{2} \mathrm{Cl}_{2}$ ) of: (top) PPYP 1 (batch with $x=$ $1, y=1 ; \mathrm{M}_{\mathrm{n}}=3,200 \mathrm{~g} \mathrm{~mol}^{-1}, \mathrm{Ð}=1.7$ ); (bottom) reaction mixture of $\mathbf{1}+[\mathrm{Rh}(\mathrm{cod}) \mathrm{Cl}]_{2}$ with $[\mathrm{Rh}]:[\mathrm{P}] \approx 1: 1$ recorded approximately 30 min of mixing. 


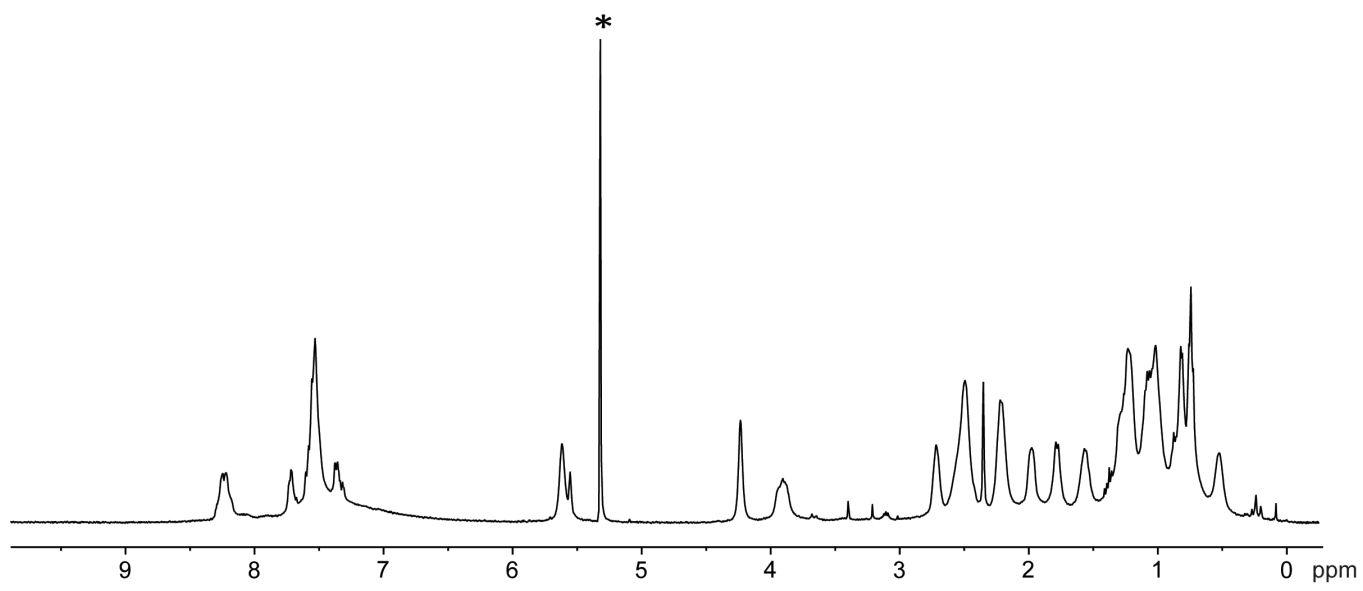

Figure S8. ${ }^{1} \mathrm{H}$ NMR $\left(400 \mathrm{MHz}, \mathrm{CD}_{2} \mathrm{Cl}_{2}\right)$ of reaction mixture of 1 (batch with $\mathrm{x}=1, \mathrm{y}=1 ; \mathrm{M}_{\mathrm{n}}=$ $3,200 \mathrm{~g} \mathrm{~mol}-1, \mathrm{Ð}=1.7)+[\mathrm{Rh}(\operatorname{cod}) \mathrm{Cl}]_{2}$ with $[\mathrm{Rh}]:[\mathrm{P}] \approx 1: 1$ recorded approximately $30 \mathrm{~min}$ of mixing. ${ }^{*}=\mathrm{CH}_{2} \mathrm{Cl}_{2} / \mathrm{CHDCl}_{2}$.

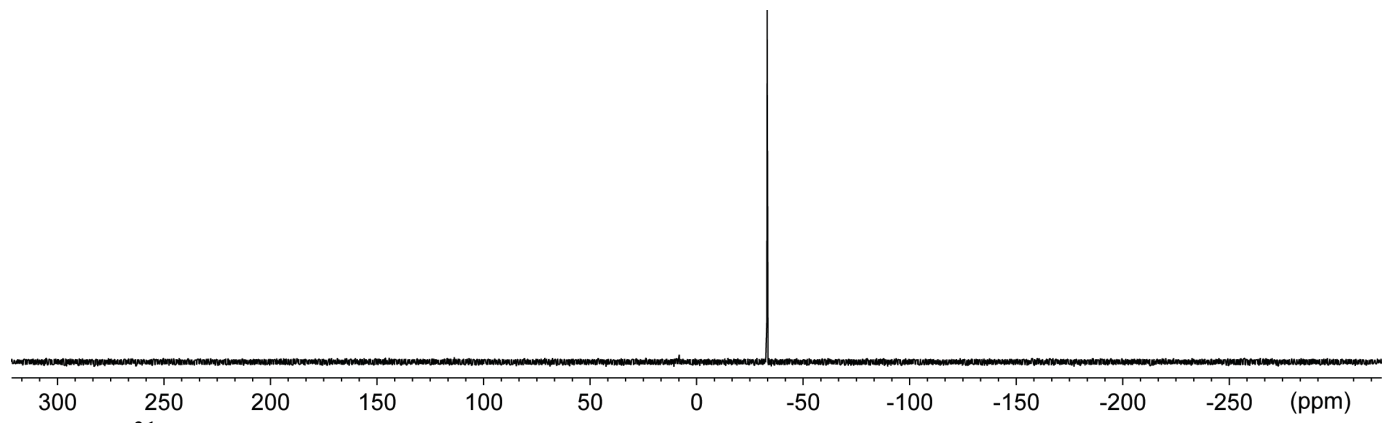

Figure S9. ${ }^{31} \mathrm{P}$ NMR spectrum $\left(162 \mathrm{MHz}, \mathrm{CDCl}_{3}\right)$ of 2.

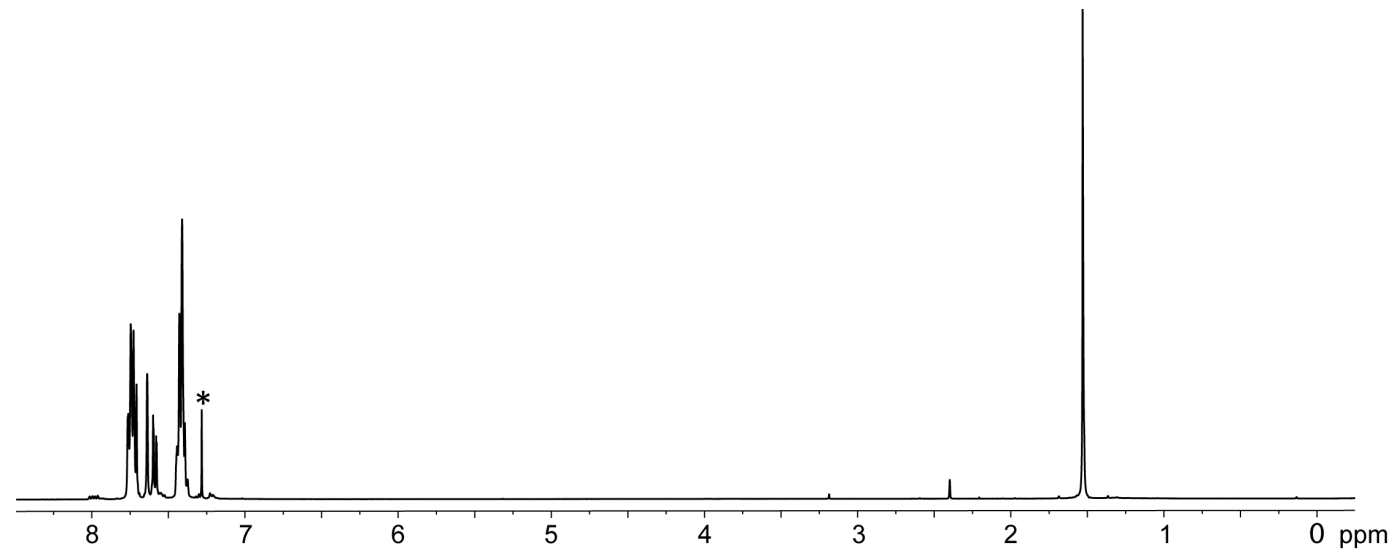

Figure S10. ${ }^{1} \mathrm{H}$ NMR spectrum $\left(400 \mathrm{MHz}, \mathrm{CDCl}_{3}\right)$ of $2 .{ }^{*}=\mathrm{CHCl}_{3}$. 


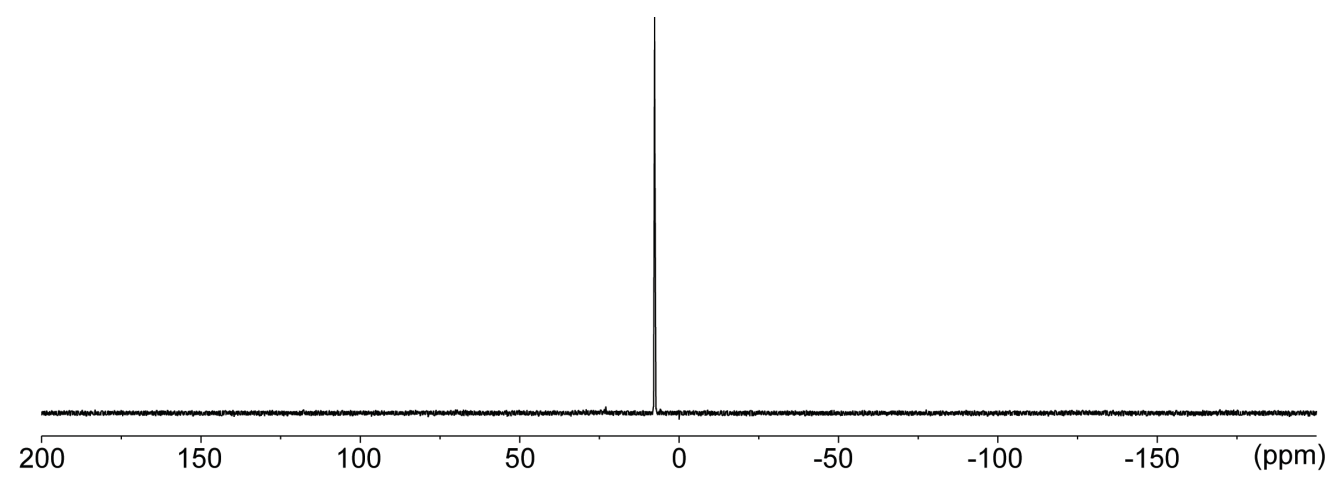

Figure S11. ${ }^{31} \mathrm{P}$ NMR spectrum $\left(162 \mathrm{MHz}, \mathrm{CD}_{2} \mathrm{Cl}_{2}\right)$ of $\mathbf{2} \cdot(0)_{2}$.

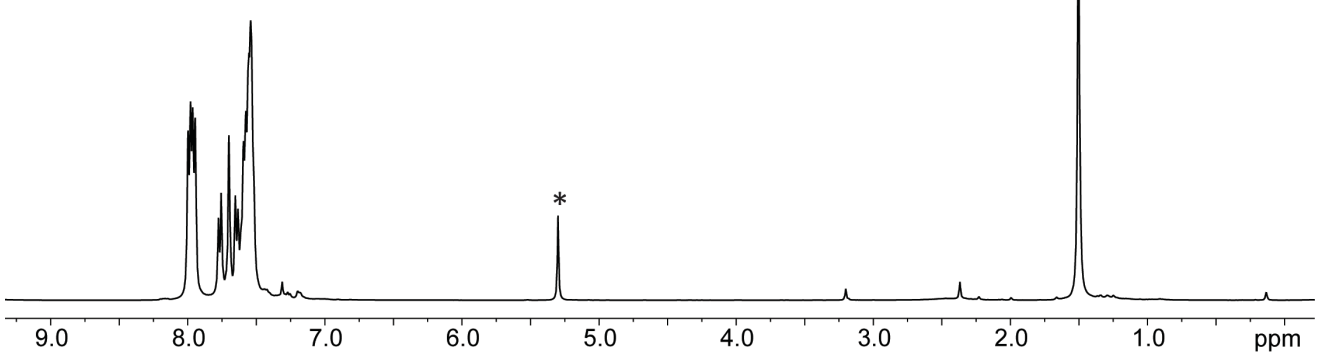

Figure S12. ${ }^{1} \mathrm{H}$ NMR spectrum $\left(400 \mathrm{MHz}, \mathrm{CDCl}_{3}\right)$ of $\mathbf{2} \cdot(0){ }_{2} \cdot{ }^{*}=\mathrm{CH}_{2} \mathrm{Cl}_{2} / \mathrm{CHDCl}_{2}$.

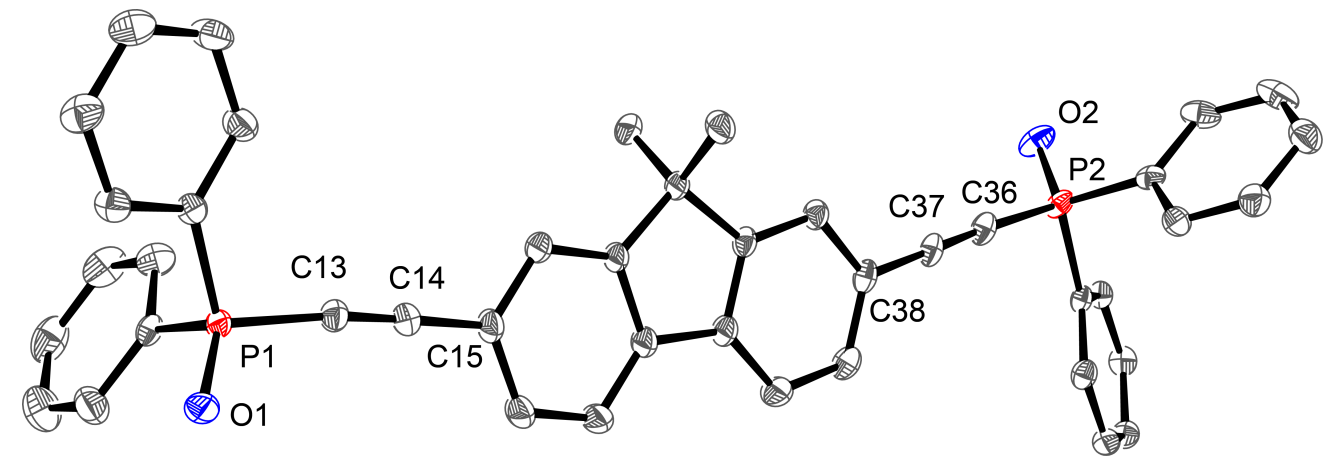

Figure S13. Molecular structure of $\mathbf{2} \cdot(0)_{2}(50 \%$ probability level). For clarity, all hydrogen atoms are omitted. Details available in the cif file.

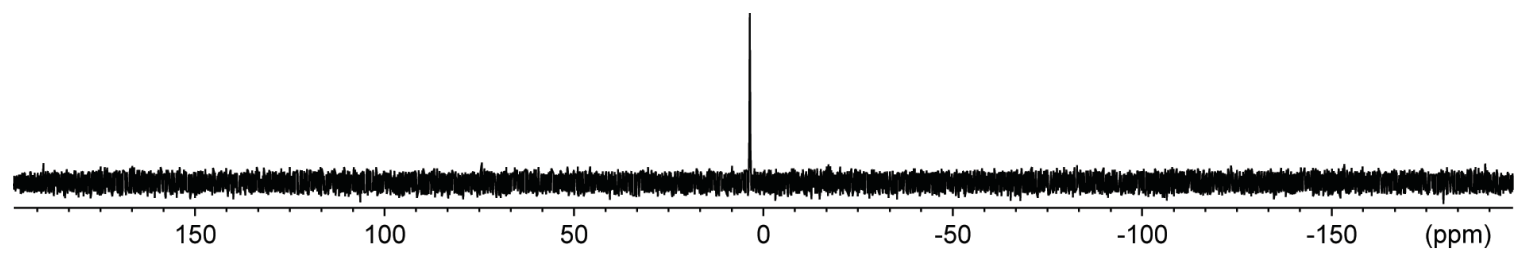

Figure S14. ${ }^{31} \mathrm{P}$ NMR spectrum $\left(162 \mathrm{MHz}, \mathrm{CDCl}_{3}\right)$ of $\mathbf{2} \cdot(\mathrm{AuCl})_{2}$. 


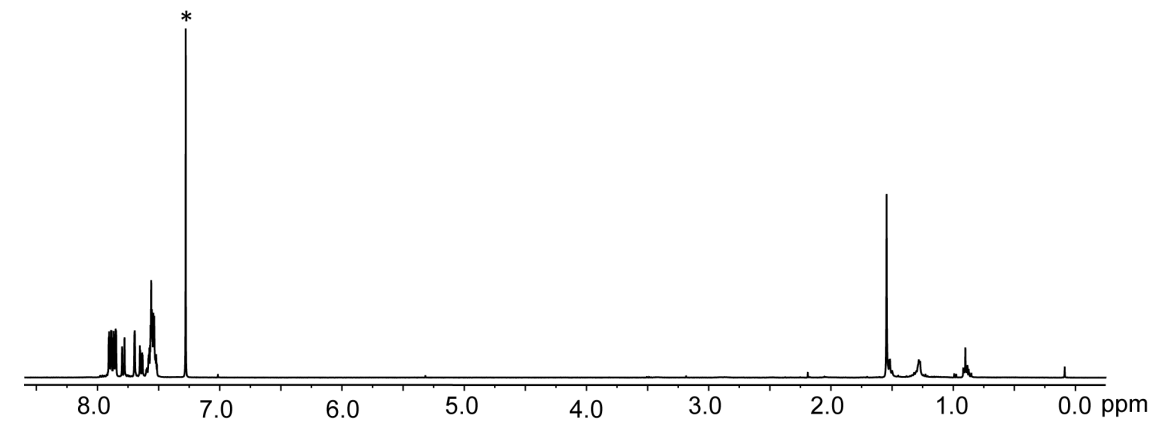

Figure S15. ${ }^{1} \mathrm{H}$ NMR spectrum $\left(400 \mathrm{MHz}, \mathrm{CDCl}_{3}\right)$ of $\mathbf{2} \cdot(\mathrm{AuCl})_{2} \cdot{ }^{*}=\mathrm{CHCl}_{3}$.

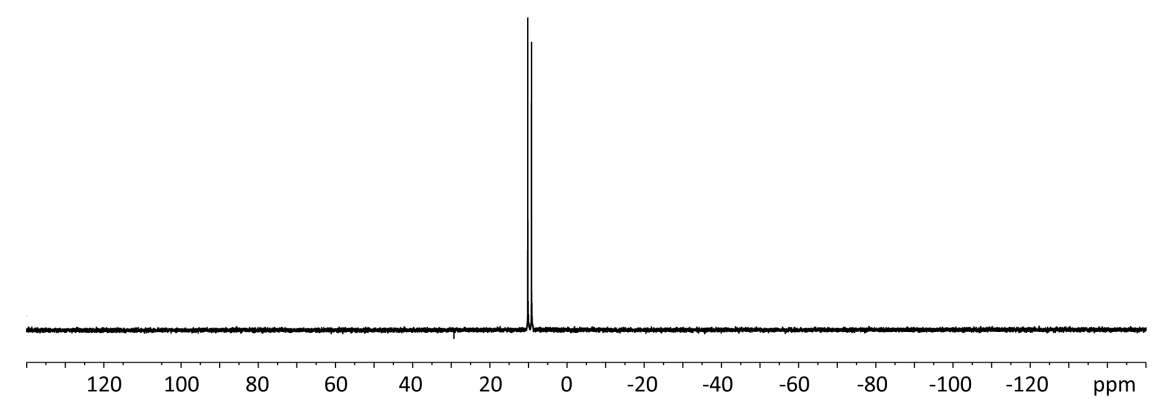

Figure S16. ${ }^{31} \mathrm{P}\{1 \mathrm{H}\}$ NMR spectrum $\left(162 \mathrm{MHz}, \mathrm{CD}_{2} \mathrm{Cl}_{2}\right)$ of $\mathbf{2} \cdot[\mathrm{Rh}(\operatorname{cod}) \mathrm{Cl}]_{2}$.

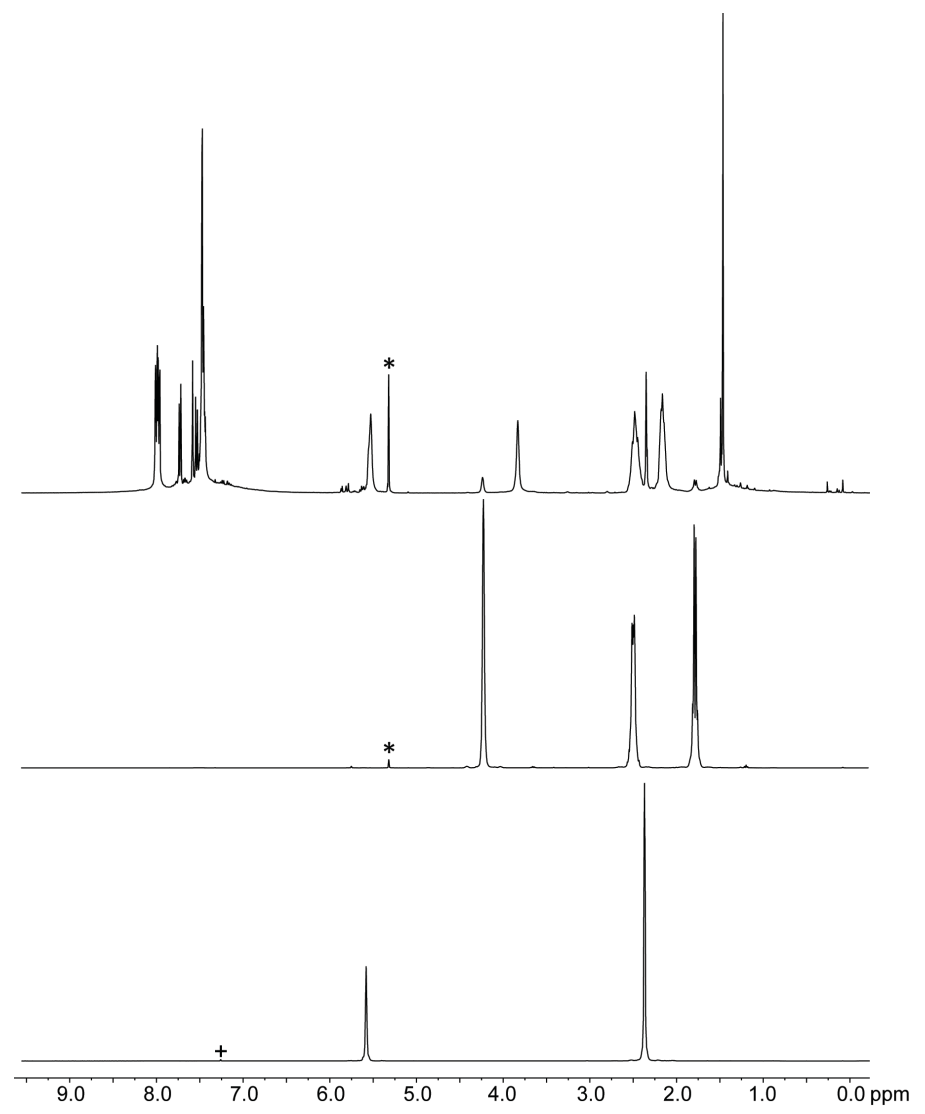

Figure S17. ${ }^{1} \mathrm{H}$ NMR spectra $(162 \mathrm{MHz}, 298 \mathrm{~K})$ of $\mathbf{2} \cdot[\mathrm{Rh} \text { (cod) } \mathrm{Cl}]_{2}$ in $\mathrm{CD}_{2} \mathrm{Cl}_{2}$ (top) and, for comparison, $[\mathrm{Rh}(\mathrm{cod}) \mathrm{Cl}]_{2}$ in $\mathrm{CD}_{2} \mathrm{Cl}_{2}$ (middle) and 1,5-COD in $\mathrm{CDCl}_{3} *=\mathrm{CH}_{2} \mathrm{Cl}_{2} / \mathrm{CHDCl}_{2},+=$ $\mathrm{CHCl}_{3}$. 


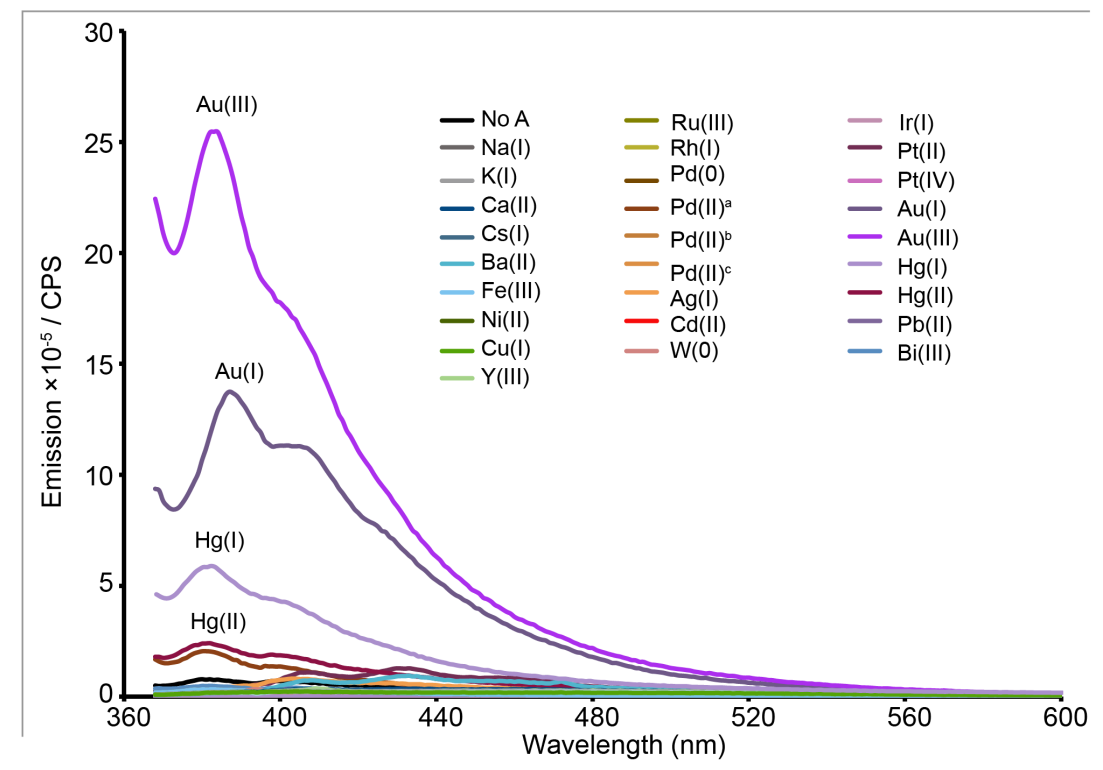

Figure S18. Emission spectra for sensing experiments performed with PPYP 1 and various metal salts (10 equiv) in THF solution.

Table S1. Raw emission data for sensing experiments performed with PPYP $\mathbf{1}$ and various metal salts (10 equiv) in THF solution. This data is depicted in Figure 1 and the emission spectra are shown in Figure S18.

\begin{tabular}{|c|c|c|c|c|c|}
\hline Analyte & $\begin{array}{c}\text { Integrated } \\
\text { Emission } \\
\end{array}$ & $\begin{array}{l}\text { Relative } \\
\text { Integrated } \\
\text { Emission } \\
\end{array}$ & $\begin{array}{c}\lambda_{\mathrm{em}} \\
(\mathbf{n m})\end{array}$ & $\begin{array}{c}\text { Emission } \\
\text { Intensity } \\
\text { at } \lambda_{\mathrm{em}} \\
\end{array}$ & $\begin{array}{c}\text { Relative } \\
\text { Emission } \\
\text { Intensity } \\
\end{array}$ \\
\hline No A & 1394830 & 1 & 380 & 78420 & 1 \\
\hline $\mathrm{NaNO}_{3}$ & 2624245 & 1.88 & 465 & 28210 & 0.36 \\
\hline $\mathrm{KNO}_{3}$ & 2216927 & 1.59 & 471 & 22510 & 0.29 \\
\hline $\mathrm{CsNO}_{3}$ & 3291723 & 2.36 & 434 & 35830 & 0.46 \\
\hline $\mathrm{Ca}\left(\mathrm{NO}_{3}\right)_{2}$ & 2516319 & 1.80 & 461 & 25970 & 0.33 \\
\hline $\mathrm{Ba}\left(\mathrm{NO}_{3}\right)_{2}$ & 2431060 & 1.74 & 466 & 26000 & 0.33 \\
\hline $\mathrm{Y}\left(\mathrm{NO}_{3}\right)_{3} \cdot 6 \mathrm{H}_{2} \mathrm{O}$ & 2525340 & 1.81 & 470 & 27030 & 0.34 \\
\hline $\mathrm{W}(\mathrm{CO})_{5} \mathrm{MeCN}$ & 1288986 & 0.92 & 403 & 30080 & 0.38 \\
\hline $\mathrm{Fe}\left(\mathrm{NO}_{3}\right)_{3} \cdot 9 \mathrm{H}_{2} \mathrm{O}$ & 6731174 & 4.83 & 433 & 95810 & 1.22 \\
\hline $\mathrm{RuCl}_{3} \cdot \mathrm{xH}_{2} \mathrm{O}$ & 46739 & 0.03 & 392 & 2780 & 0.04 \\
\hline$[\mathrm{Rh}(\operatorname{cod}) \mathrm{Cl}]_{2}$ & 270247 & 0.19 & 393 & 5570 & 0.07 \\
\hline$[\operatorname{Ir}(\operatorname{cod}) \mathrm{Cl}]_{2}$ & 874046 & 0.63 & 394 & 32050 & 0.41 \\
\hline $\mathrm{Ni}\left(\mathrm{NO}_{3}\right)_{2} \cdot 6 \mathrm{H}_{2} \mathrm{O}$ & 3063430 & 2.20 & 404 & 32830 & 0.42 \\
\hline $\mathrm{Pd}\left(\mathrm{PPh}_{3}\right)_{4}$ & 1837594 & 1.32 & 380 & 32800 & 0.42 \\
\hline $\mathrm{PdCl}_{2}$ & 3041850 & 2.18 & 381 & 204800 & 2.61 \\
\hline $\mathrm{Pd}(\mathrm{OAc})_{2}$ & 459110 & 0.33 & 399 & 13100 & 0.17 \\
\hline $\mathrm{Pd}\left(\mathrm{PPh}_{3}\right)_{2} \mathrm{Cl}_{2}$ & 13545 & 0.01 & 407 & 810 & 0.01 \\
\hline
\end{tabular}




\begin{tabular}{|c|c|c|c|c|c|}
\hline $\mathrm{PtCl}_{2}$ & 7053953 & 5.06 & 433 & 127750 & 1.63 \\
\hline $\mathrm{K}_{2} \mathrm{PtCl}_{4}$ & 1152485 & 0.83 & 401 & 32500 & 0.41 \\
\hline $\mathrm{Cu}\left(\mathrm{NO}_{3}\right)_{2} \cdot 5 \mathrm{H}_{2} \mathrm{O}$ & 1845099 & 1.32 & 472 & 19500 & 0.25 \\
\hline $\mathrm{AgNO}_{3}$ & 4453315 & 3.19 & 403 & 81320 & 1.04 \\
\hline $\mathrm{Au}($ tht $) \mathrm{Cl}$ & 49492558 & 35.48 & 387 & 1374250 & 17.52 \\
\hline $\mathrm{HAuCl}_{4} \cdot 3 \mathrm{H}_{2} \mathrm{O}$ & 130748845 & 93.74 & 383 & 2545900 & 32.46 \\
\hline $\mathrm{Cd}\left(\mathrm{NO}_{3}\right)_{2} \cdot 4 \mathrm{H}_{2} \mathrm{O}$ & 2800165 & 2.01 & 401 & 31550 & 0.4 \\
\hline $\mathrm{Hg}_{2}\left(\mathrm{NO}_{3}\right)_{2}$ & 24862853 & 17.83 & 382 & 577400 & 7.36 \\
\hline $\mathrm{Hg}\left(\mathrm{NO}_{3}\right)_{2} \cdot \mathrm{H}_{2} \mathrm{O}$ & 8295275 & 5.95 & 382 & 241000 & 3.07 \\
\hline $\mathrm{Pb}\left(\mathrm{NO}_{3}\right)_{2}$ & 2756404 & 1.98 & 404 & 30940 & 0.39 \\
\hline $\mathrm{Bi}\left(\mathrm{NO}_{3}\right)_{3} \cdot 5 \mathrm{H}_{2} \mathrm{O}$ & 1576277 & 1.13 & 382 & 48850 & 0.62 \\
\hline
\end{tabular}

Table S2. Absorbance and emission data for isolated polymers $\mathbf{1} \cdot(0)_{n}, \mathbf{1} \cdot(\mathrm{AuCl})_{n}$ and model compounds $2 \cdot(0)_{2}$ and $2 \cdot(\mathrm{AuCl})_{2}$.

\begin{tabular}{|c|c|c|c|c|c|c|c|}
\hline \multirow[t]{3}{*}{ Compound } & \multirow{3}{*}{$\frac{\lambda_{\mathrm{abs}} / \mathrm{nm}}{\left(\varepsilon / \mathrm{M}^{-1} \mathrm{~cm}^{-1}\right)}$} & \multirow[t]{3}{*}{$\lambda_{\text {ex }} / \mathrm{nm}^{(\mathrm{a})}$} & \multirow[t]{3}{*}{$\lambda_{\mathrm{em}} / \mathrm{nm}^{(\mathrm{b})}$} & \multirow{2}{*}{\multicolumn{3}{|c|}{$\begin{array}{c}\text { emission lifetimes } / \mathrm{ns} \\
\text { (\% contribution) }\end{array}$}} & \multirow[t]{3}{*}{$\Phi_{\text {soln }}$} \\
\hline & & & & & & & \\
\hline & & & & $\tau_{1}$ & $\tau_{2}$ & $\tau_{3}$ & \\
\hline 1 & $\begin{array}{l}353(26,956) \\
332(30,060) \\
296(32,200)\end{array}$ & $\mathrm{N} / \mathrm{A}$ & 381 & N/A & & & N/A \\
\hline $1 \cdot 0$ & $\begin{array}{l}353(12,870) \\
330(15,360) \\
296(17,830)\end{array}$ & 354 & 381 & $1.3(40)$ & $0.3(46)$ & $4.0(14)$ & 0.30 \\
\hline $\mathbf{1} \cdot \mathrm{AuCl}$ & $\begin{array}{l}360(9,730) \\
334(12,030) \\
304(11,913)\end{array}$ & 359 & 387 & $0.2(55)$ & $1.1(34)$ & $3.6(11)$ & 0.08 \\
\hline 2 & $\begin{array}{c}353(42,780) \\
336(42,950) \\
312(21,320)\end{array}$ & & 390 & & & & \\
\hline $2 \cdot 0$ & $\begin{array}{l}345(47,890) \\
326(44,160) \\
306(26,520)\end{array}$ & 346 & 369 & $0.9(57)$ & $1.0(33)$ & $3.5(9)$ & 0.57 \\
\hline $2 \cdot \mathrm{AuCl}$ & $\begin{array}{l}351(47,450) \\
333(38,190) \\
309(18,210)\end{array}$ & 353 & 378 & $0.9(52)$ & $1.3(37)$ & $4.4(11)$ & 0.15 \\
\hline
\end{tabular}

(a) $\lambda_{\text {ex }}$ is the peak maximum in the excitation spectrum using $\lambda_{\text {em }}$ maximum. (b) $\lambda_{\text {em }}$ is the maximum in the emission spectrum when excited at $\lambda_{\text {ex. }}$. 

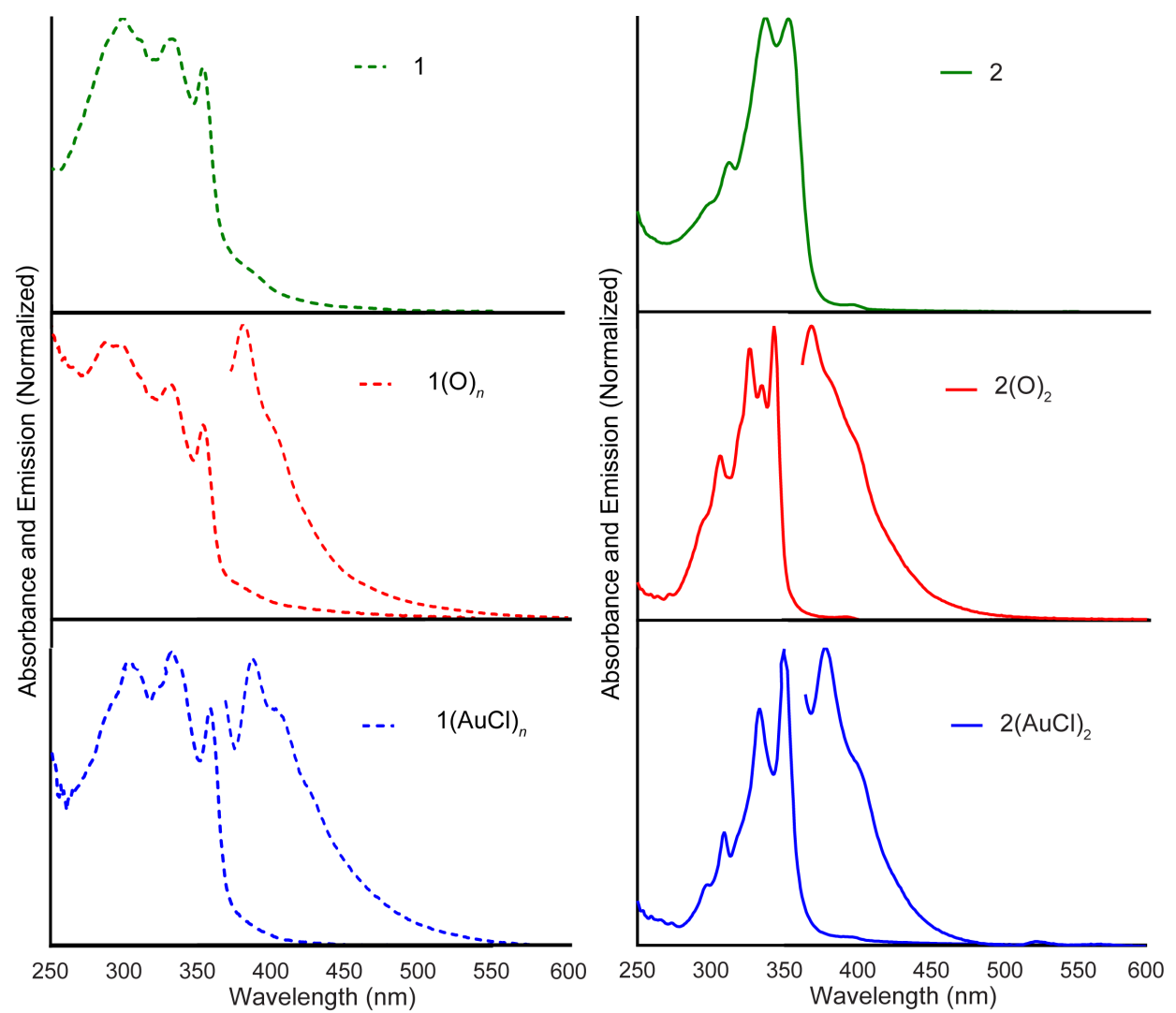

Figure S19. Absorption and emission spectra of isolated PPYPs 1, 1.(O) $)_{n}$ and $\mathbf{1} \cdot(\mathrm{AuCl})_{\mathrm{n}}$ and the corresponding model compounds $\mathbf{2}, \mathbf{2} \cdot(\mathrm{O})_{2}$ and $\mathbf{2} \cdot(\mathrm{AuCl}) \mathrm{n}(\mathrm{c}=20 \mu \mathrm{M}$ in THF).

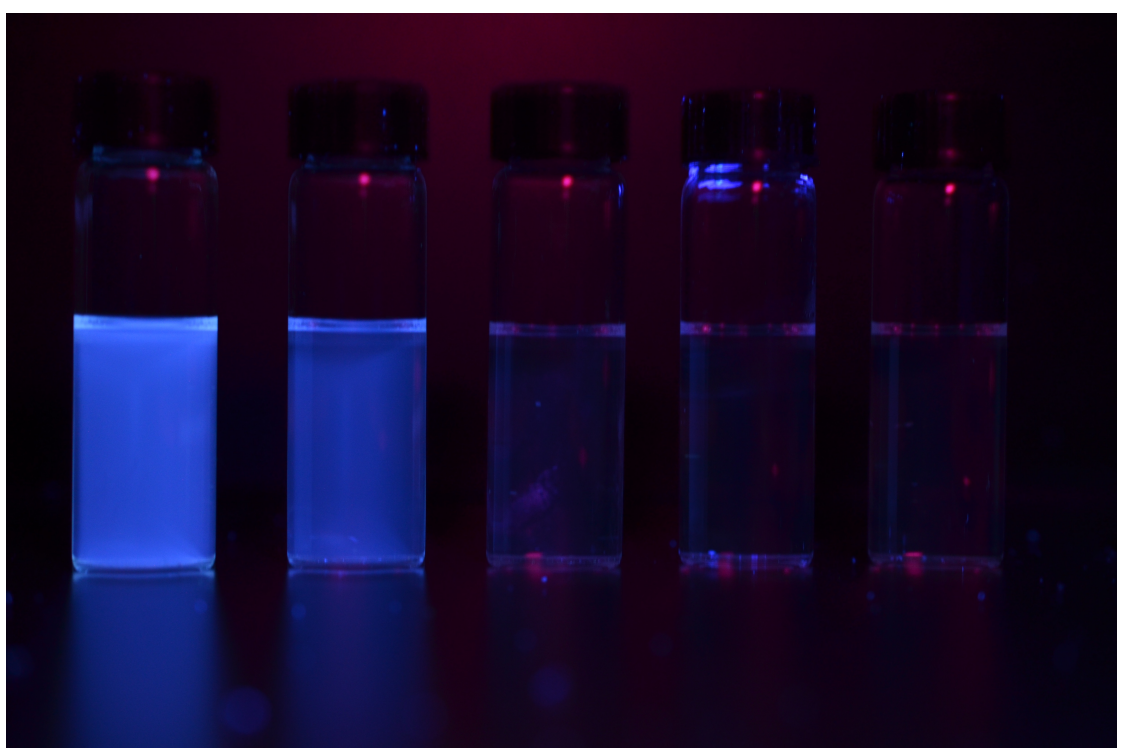

Figure S20. Photograph of solutions of 1 (batch with $\mathrm{x}=1, \mathrm{y}=1 ; \mathrm{M}_{\mathrm{n}}=3,200 \mathrm{~g} \mathrm{~mol}^{-1}, \mathrm{D}=$ 1.7) and $\mathrm{Au}$ (tht) $\mathrm{Cl}$ in THF with $[\mathrm{Au}]:[\mathrm{P}] \approx 1: 1$ at the following concentrations (left to right): $21 \mathrm{ppm} \mathrm{Au}, 2.1 \mathrm{ppm}$ in $\mathrm{Au}, 210 \mathrm{ppb}$ in $\mathrm{Au}, 21 \mathrm{ppb}$ in $\mathrm{Au}$ and pure THF. Solutions were irradiated with a UV lamp $(\lambda=365 \mathrm{~nm})$. 


\section{X-ray Crystallography}

All single crystals were immersed in oil and mounted on a glass fiber. Data were collected at $90 \pm 0.1 \mathrm{~K}$ on a Bruker X8 APEX 2 diffractometer with graphitemonochromated Mo $\mathrm{K} \square$ radiation. Data were collected and integrated using the Bruker SAINT6 ${ }^{6}$ software package and corrected for absorption effects with SADABS.7 All data sets were corrected for Lorentz and polarization effects. All structures were solved by direct methods ${ }^{8}$ and subsequent Fourier difference techniques and refined anisotropically for all non-hydrogen atoms using the SHELXTL $^{9}$ crystallographic software package from Bruker-AXS. Additional crystal data and details of the data collection and structure refinement are given in Table S3 and the CIF files. None of the crystals presented crystallographic complications.

Table S3: Crystallographic parameters for model compounds $2,2 \cdot(0)_{2}$ and $2 \cdot(\mathrm{AuCl})_{2}$.

\begin{tabular}{llll}
\hline & $\mathbf{2}$ & $\mathbf{2 \cdot ( O )})_{2}$ & $\mathbf{2 \cdot ( A u C l})_{2}$ \\
\hline Empirical formula & $\mathrm{C}_{43} \mathrm{H}_{32} \mathrm{P}_{2}$ & $\mathrm{C}_{43} \mathrm{H}_{32} \mathrm{O}_{2} \mathrm{P}_{2}$ & $\mathrm{C}_{43} \mathrm{H}_{32} \mathrm{Au}_{2} \mathrm{Cl}_{2} \mathrm{P}_{2}$ \\
FW & 610.62 & 642.62 & 1075.46 \\
Crystal system & orthorhombic & monoclinic & monoclinic \\
Space group & $\mathrm{P} 2_{1} 2_{1} 2_{1}$ & $\mathrm{P} 2{ }_{1} / \mathrm{c}$ & $\mathrm{C} 2 / \mathrm{c}$ \\
$a[\AA]$ & $5.9827(8)$ & $8.3642(4)$ & $29.6193(19)$ \\
$b[\AA]$ & $15.686(2)$ & $22.4504(10)$ & $11.3651(7)$ \\
$c[\AA]$ & $34.121(5)$ & $17.9320(8)$ & $12.9080(8)$ \\
$\mathrm{a}\left[^{\circ}\right]$ & 90 & 90 & 90 \\
$\beta\left[^{\circ}\right]$ & 90 & $95.4680(10)$ & $103.804(2)$ \\
$\gamma\left[^{\circ}\right]$ & 90 & 90 & 90 \\
$V\left[^{3}\right]$ & $3201.9(8)$ & $3351.9(3)$ & $4219.7(5)$ \\
$T\left[^{3}\right]$ & 296.15 & 273.15 & $90(2)$ \\
$\mathrm{Z}$ & 4 & 4 & 4 \\
$\mathrm{~F}(000)$ & 1280.0 & 1344.0 & 2048.0 \\
No. of reflections & 39707 & 10218 & 27164 \\
collected $_{\text {Goodness of fit on } F^{2}}$ & 1.081 & 1.119 & 1.042 \\
$R_{1}[\mathrm{I}>2 \sigma(\mathrm{I})]^{a}$ & 0.0461 & 0.0567 & 0.0250 \\
$w R_{2}\left[\right.$ all data ${ }^{b}$ & 0.1087 & 0.1504 & 0.0586 \\
$\mathrm{CCDC}$ & 1961504 & 1961505 & 1961506 \\
\hline
\end{tabular}

${ }^{a} R_{1}=\Sigma|| F_{\mathrm{o}}|-| F_{\mathrm{c}}|| / \Sigma\left|F_{\mathrm{o}}\right| \cdot{ }^{b} \mathrm{w} R_{2}\left(F^{2}[\right.$ all data $\left.]\right)=\left\{\Sigma\left[w\left(F_{\mathrm{o}}{ }^{2}-F_{\mathrm{c}}{ }^{2}\right)^{2}\right] / \Sigma\left[w\left(F_{\mathrm{o}}{ }^{2}\right)^{2}\right]\right\}^{1 / 2}$ 


\section{Computational details}

Density functional theory calculations were performed in Gaussian 09 (Revision D.01).10 Initial geometry optimizations were performed using the B3LYP functional with no symmetry confinements. In the case of $\mathbf{2}, \mathbf{2} \cdot(0)_{2}$ and $\mathbf{2} \cdot(\mathrm{AuCl})_{2}$, where crystal structures were available, this was used as the initial input geometry prior to optimization. For the geometry optimizations of $\mathbf{2}$ and $\mathbf{2} \cdot(0)_{2}$ Pople basis set $6-31 \mathrm{G}^{*}$ was used for all atoms. ${ }^{11}$ For geometry optimizations of models $2 \cdot(\mathrm{AuCl})_{2}$ and $2 \cdot[\mathrm{Rh}(\mathrm{cod}) \mathrm{Cl}]_{2}$ the $6-31 \mathrm{G}^{*}$ basis set was used for all atoms apart from $\mathrm{Au}$ and $\mathrm{Rh}$, where the LANL2DZ basis set and effective core potentials were used.12-14 A converged ground state was found for each molecule. Time dependent DFT 15,16 was used to calculate absorption maxima of $\mathbf{2}, \mathbf{2} \cdot(0)_{2}, \mathbf{2} \cdot(\mathrm{AuCl})_{2}$ and $2 \cdot\left[\mathrm{Rh}(\mathrm{cod}) \mathrm{Cl}_{2}\right.$ using the aforementioned basis sets with the CAM-B3LYP functional. Additionally, solvation corrections were implemented using the polarizable continuum model using tetrahydrofuran $(\varepsilon=7.43)$ as solvent. ${ }^{17}$ The first 20 singlet states and first 20 triplet states were calculated for each model. From this calculation the excited state of interest was identified (by the presence of a high oscillator strength) and optimized in order to obtain the excited state geometry. For $\mathbf{2}$ and $\mathbf{2} \cdot(0)_{2}$ the excited state geometry optimization was performed using the CAM-B3LYP functional, 6-31G* basis set with solvation corrections using tetrahydrofuran $(\varepsilon=7.43)$ as solvent. For the geometry optimization of $\mathbf{2} \cdot(\mathrm{AuCl})_{2}$ and $2 \cdot\left[\mathrm{Rh}(\operatorname{cod}) \mathrm{Cl}_{2}\right.$ the less computationally expensive B3LYP functional was used with the $6-31 \mathrm{G}^{*}(\mathrm{C}, \mathrm{H}, \mathrm{P}, \mathrm{Cl})$ and LANL2DZ (Au and $\mathrm{Rh}$ ) basis sets with solvation correction. We were able to obtain a converged excited state structure for $2 \cdot(\mathrm{AuCl})_{2}$ using the "opt=Loose" keyword. For $\mathbf{2} \cdot[\mathrm{Rh}(\mathrm{cod}) \mathrm{Cl}]_{2}$ we were to obtain a structure which satisfied the "Loose" convergence criteria for maximum force, root means squared force, and root means squared displacement however this structure did not satisfy convergence criteria for maximum displacement of atoms (value $=0.0126$, threshold $=0.0100$ ) and was not pursued further. Time dependent DFT calculations was performed on the optimized excited state structures in order to compute the emission maxima for $2, \mathbf{2} \cdot(\mathrm{O})_{2}$ and $2 \cdot(\mathrm{AuCl})_{2}$. This was done using the CAM-B3LYP functional using the 6-31G* (for $\mathrm{C}, \mathrm{H}, \mathrm{O}, \mathrm{P}, \mathrm{Cl}$ ) and LANL2DZ $(\mathrm{Au})$ basis sets with the aforementioned solvation correction. The results of all calculations are tabulated below along with figures showing the key frontier orbitals. 
a)

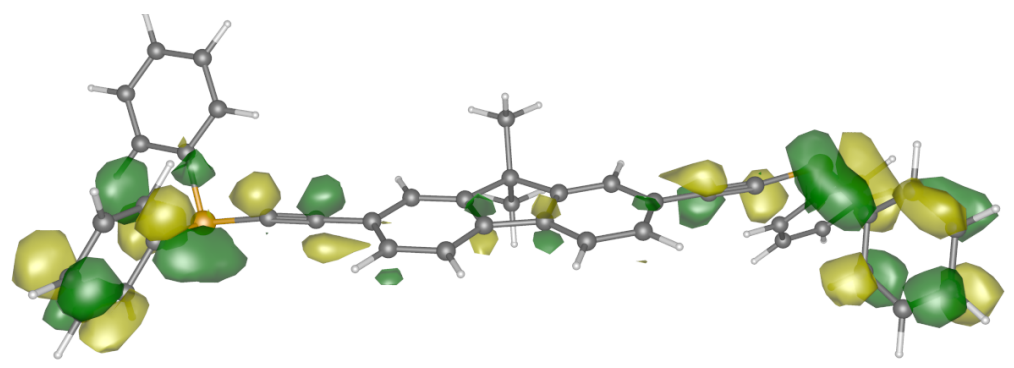

LUMO+1 (M0162)

b)

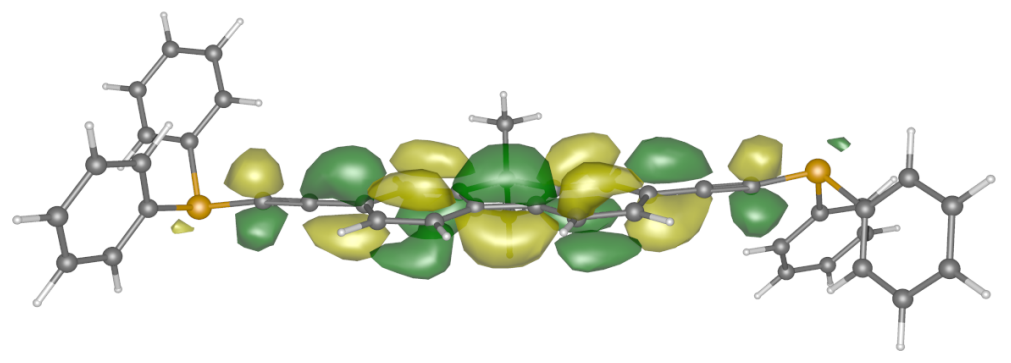

LUMO+1 (M0161)

c)

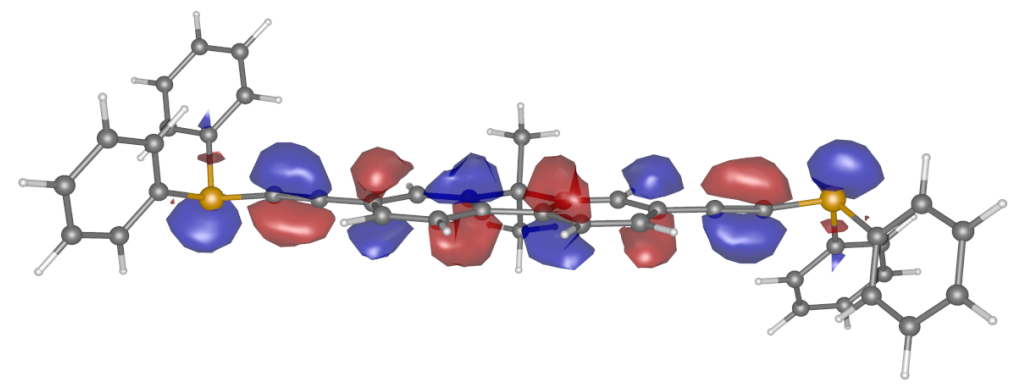

HOMO (M0160)

d)

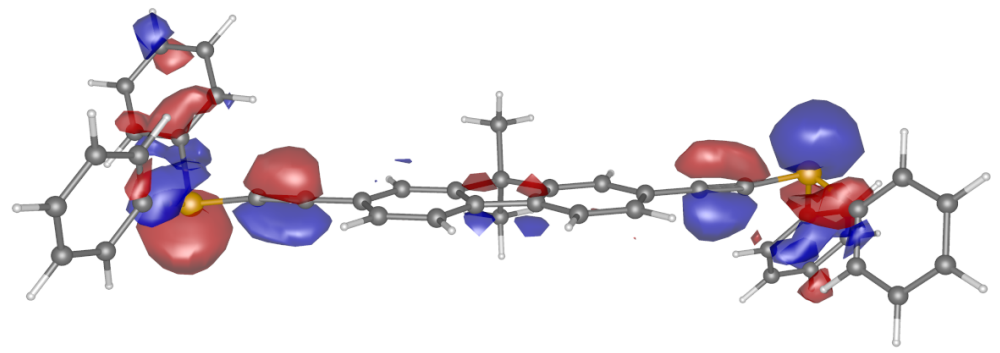

HOMO-1 (M0159)

Figure S21. a) LUMO+1 (MO 162), b) LUMO (M0161), c) HOMO (M0160), d) HOMO-1

(M0159) of ground state phosphine 2 
Table S4. Predicted Singlet Absorption Maxima for 2 (CAM-B3LYP/6-31G*)

\begin{tabular}{|c|c|c|c|}
\hline $\begin{array}{l}\text { Excited } \\
\text { State \# }\end{array}$ & $\begin{array}{l}\text { Wavlength } \\
(n m)\end{array}$ & $\begin{array}{l}\text { Oscillator } \\
\text { Strength }\end{array}$ & M0 Transitions (Configuration Interaction) \\
\hline 1 & 327.93 & 2.1366 & $159 \rightarrow 162(-0.11602), 160 \rightarrow 161(0.66867)$ \\
\hline 2 & 273.1 & 0.0647 & $\begin{aligned} 157 & \rightarrow 161(0.11878), 159 \rightarrow 161(0.45838), 159 \rightarrow 163(0.12838) \\
159 & \rightarrow 165(0.14435), 160 \rightarrow 162(-0.33240), 160 \rightarrow 164(-0.16218)\end{aligned}$ \\
\hline 3 & 261.66 & 0.0032 & $\begin{array}{c}150 \rightarrow 161(0.35656), 156 \rightarrow 161(-0.12669), 158 \rightarrow 161(0.11315), 158 \rightarrow 166 \\
(0.12287), 159 \rightarrow 162(0.14209), 160 \rightarrow 163(-0.12144) 160 \rightarrow 165(- \\
0.19514), 160 \rightarrow 166(0.41968)\end{array}$ \\
\hline 4 & 256.43 & 0.0658 & 10 contributions to transition \\
\hline 5 & 255.08 & 0.0175 & $\begin{aligned} 155 \rightarrow 161(0.53915), 159 & \rightarrow 166(0.11842), 160 \rightarrow 169(0.13528) \\
160 & \rightarrow 172(-0.30347)\end{aligned}$ \\
\hline 6 & 248.95 & 0.0212 & $\begin{array}{c}159 \rightarrow 161(-0.29485), 159 \rightarrow 163(0.14724), 159 \rightarrow 165(0.24633), 159 \rightarrow 174 \\
(0.15509), 160 \rightarrow 162(-0.15761), 160 \rightarrow 167(0.36183), 160 \rightarrow 173(-0.20511)\end{array}$ \\
\hline 7 & 239.15 & 0.0399 & 10 contributions to transition \\
\hline 8 & 238.17 & 0.1659 & 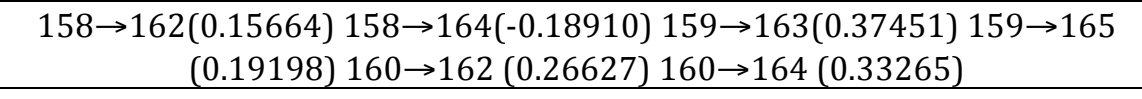 \\
\hline 9 & 236.29 & 0.0063 & $\begin{aligned} 146 & \rightarrow 161(0.21803) 147 \rightarrow 162(0.10112) 148 \rightarrow 161(0.13171) \\
156 & \rightarrow 161(0.28333) 158 \rightarrow 161(-0.21608) 158 \rightarrow 163(0.12665) \\
159 & \rightarrow 164(-0.20589) 159 \rightarrow 167(-0.15431) 160 \rightarrow 163(-0.25101)\end{aligned}$ \\
\hline 10 & 232.23 & 0.021 & 11 contributions to transition \\
\hline
\end{tabular}

Table S5. Predicted Triplet Absorption Maxima for 2 (CAM-B3LYP/6-31G*)

\begin{tabular}{|c|c|c|c|}
\hline $\begin{array}{l}\text { Excited } \\
\text { State \# }\end{array}$ & $\begin{array}{l}\text { Wavlength } \\
\text { (nm) }\end{array}$ & $\begin{array}{l}\text { Oscillator } \\
\text { Strength }\end{array}$ & MO Transitions (Configuration Interaction) \\
\hline 1 & 531.66 & 0 & $\begin{array}{l}150 \rightarrow 166(-0.15182), 155 \rightarrow 172(0.12897), 158 \rightarrow 161 \\
(0.15868), 160 \rightarrow 161(0.60201), 160 \rightarrow 161(0.11658)\end{array}$ \\
\hline 2 & 396.73 & 0 & 10 contributions to transitions \\
\hline 3 & 360.84 & 0 & 12 contributions to transitions \\
\hline 4 & 360.81 & 0 & 12 contributions to transitions \\
\hline 5 & 357.92 & 0 & 14 contributions to transition \\
\hline 6 & 357.92 & 0 & 14 contributions to transition \\
\hline 7 & 299.6 & 0 & 11 contributions to transition \\
\hline 8 & 296.19 & 0 & $\begin{array}{c}150 \rightarrow 172(-0.31692), 155 \rightarrow 161(0.35868), 155 \rightarrow 166(0.35099), \\
159 \rightarrow 161(0.18139), 160 \rightarrow 162(-0.13659)\end{array}$ \\
\hline 9 & 295.00 & 0 & $\begin{aligned} 150 \rightarrow 161(-0.39001), 158 & \rightarrow 166(0.13422), 160 \rightarrow 165(- \\
0.10912), 160 & \rightarrow 166(0.44596)\end{aligned}$ \\
\hline 10 & 291.05 & 0 & $\begin{array}{c}150 \rightarrow 162(-0.10451), 150 \rightarrow 167(-0.12546), 150 \rightarrow 169(-0.13718), \\
155 \rightarrow 161(0.48184), 155 \rightarrow 166(-0.21997), 159 \rightarrow 161(- \\
0.14747), 160 \rightarrow 172(0.19730)\end{array}$ \\
\hline
\end{tabular}


a)

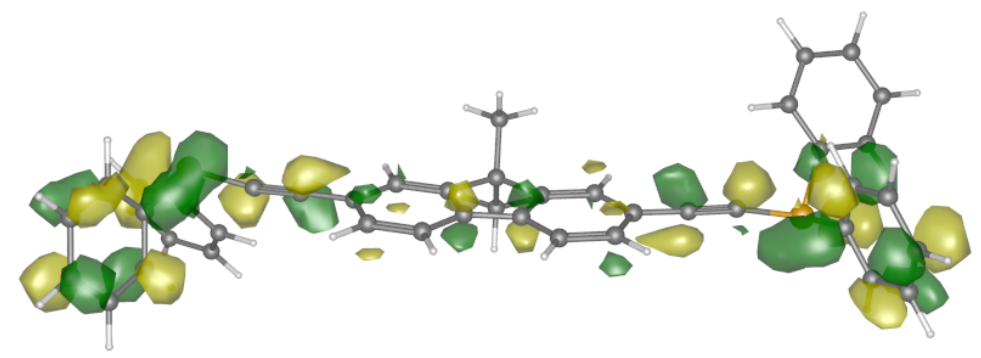

LUMO+1 (M0162)

b)

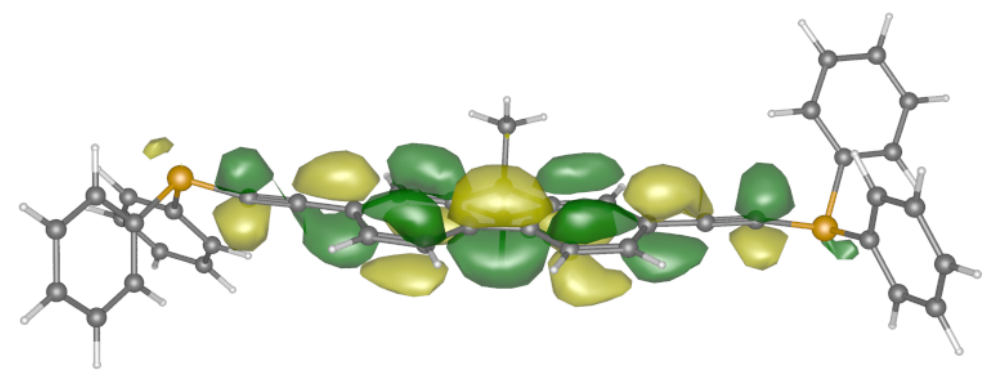

c)

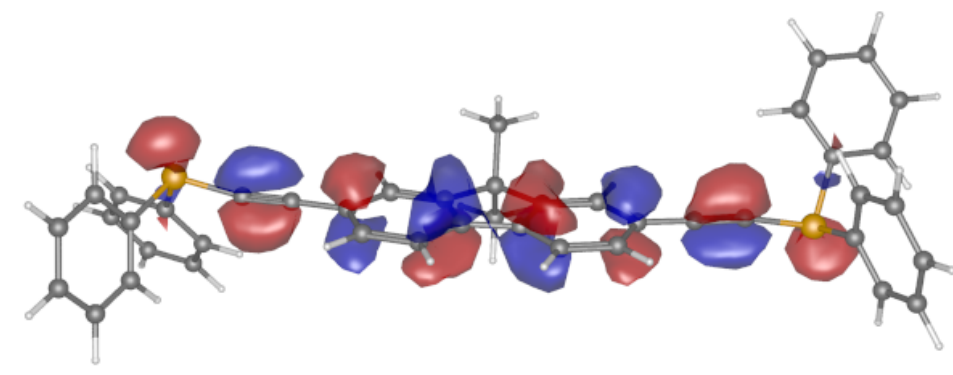

HOMO (M0160)

d)

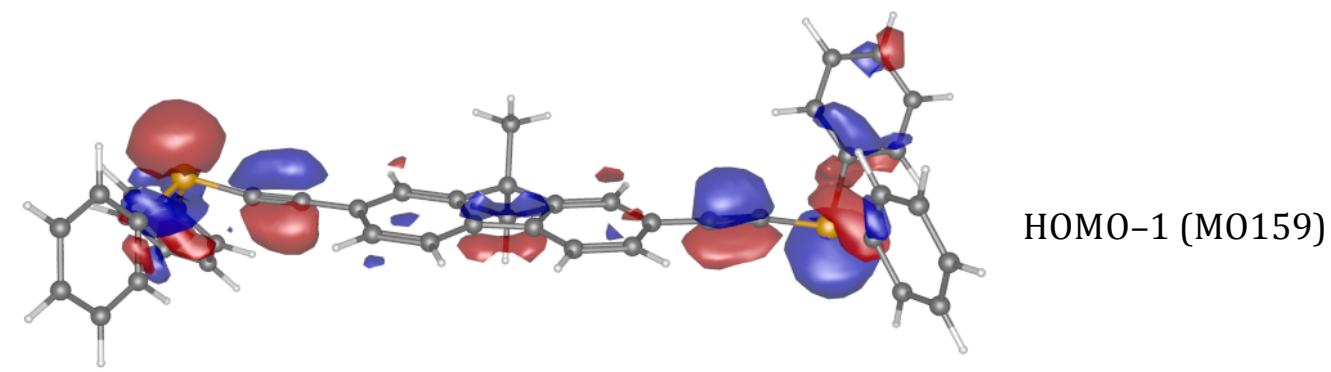

Figure S22. a) LUMO+1 (MO 162), b) LUMO (M0161), c) HOMO (M0160), d) HOMO-1 (M0159) after geometry optimization of the first singlet excited state of phosphine 2 
Table S6. Predicted Singlet Emission Maxima for 2 (CAM-B3LYP/6-31G*)

\begin{tabular}{|c|c|c|c|}
\hline Excited State \# & Wavlength (nm) & Oscillator Strength & MO Transitions (Configuration Interaction) \\
\hline 1 & 381.87 & 2.2272 & $162 \rightarrow 159(0.10009), 161 \rightarrow 160(0.68204)$ \\
\hline 2 & 291.54 & 0.0497 & $\begin{array}{l}161 \rightarrow 157(-0.11786), 162 \rightarrow 158(0.10494) 161 \rightarrow 159 \\
(0.52066), 163 \rightarrow 159(-0.10639) 165 \rightarrow 159(-0.11276) \\
162 \rightarrow 160(0.30643) 164 \rightarrow 160(-0.12842)\end{array}$ \\
\hline 3 & 271.23 & 0.0118 & $\begin{array}{l}161 \rightarrow 149(-0.25327), 161 \rightarrow 156(-0.12452), 161 \rightarrow 158 \\
(-0.17465), 162 \rightarrow 159(-0.23701), 166 \rightarrow 159(0.11697), \\
173 \rightarrow 159(0.10752) 163 \rightarrow 160(0.22559) 165 \rightarrow 160 \\
(0.25931), 167 \rightarrow 160(0.29048), 174 \rightarrow 160(0.14660)\end{array}$ \\
\hline 4 & 267.98 & 0.0171 & $\begin{array}{l}161 \rightarrow 149(-0.29833) 162 \rightarrow 159(0.16342) \\
166 \rightarrow 159(-0.13718) 163 \rightarrow 160(-0.17516) \\
165 \rightarrow 160(-0.18317) 167 \rightarrow 160(0.43845), 174 \rightarrow 160 \\
(-0.13242)\end{array}$ \\
\hline 5 & 263.55 & 0.0013 & $\begin{array}{l}161 \rightarrow 151(0.28111), 161 \rightarrow 159(0.28843), 163 \rightarrow 159 \\
(0.15148), 165 \rightarrow 159(0.19050), 174 \rightarrow 159(0.12114) \\
162 \rightarrow 160(-0.26330), 166 \rightarrow 160(0.23327), 172 \rightarrow 160 \\
(-0.17293) 173 \rightarrow 160(0.17573)\end{array}$ \\
\hline 6 & 262.64 & 0.0332 & $\begin{array}{l}161 \rightarrow 151(0.47464) 161 \rightarrow 159(-0.10430), 165 \rightarrow 159 \\
(-0.11739) 167 \rightarrow 159(0.10456), 166 \rightarrow 160(-0.24466), \\
172 \rightarrow 160(-0.27339), 173 \rightarrow 160(-0.12199)\end{array}$ \\
\hline 7 & 250.45 & 0.012 & $\begin{array}{l}161 \rightarrow 146(0.20437), 162 \rightarrow 147(-0.12472), 161 \rightarrow 148 \\
(0.14155), 161 \rightarrow 156(0.29543) 161 \rightarrow 158(0.35193) \\
166 \rightarrow 159(0.19690), 165 \rightarrow 160(0.20403), 168 \rightarrow 160 \\
(0.10596), 174 \rightarrow 160(0.12793)\end{array}$ \\
\hline 8 & 246.46 & 0.0607 & $\begin{array}{l}161 \rightarrow 147(0.14830), 161 \rightarrow 150(0.10828), 161 \rightarrow 157 \\
(0.10457), 164 \rightarrow 158(0.16303), 163 \rightarrow 159(-0.27154), \\
165 \rightarrow 159(0.18341), 162 \rightarrow 160(0.33713), 164 \rightarrow 160 \\
(0.23874), 166 \rightarrow 166(0.21767)\end{array}$ \\
\hline 9 & 245.34 & 0.0304 & $\begin{array}{l}161 \rightarrow 146(0.12372), 161 \rightarrow 156(0.12925), 163 \rightarrow 158 \\
(0.20062), 162 \rightarrow 159(-0.21138), 164 \rightarrow 159(-0.31596), \\
163 \rightarrow 160(0.38775), 165 \rightarrow 160(-0.24034)\end{array}$ \\
\hline 10 & 243.87 & 0.06 & 11 contributions to transition \\
\hline
\end{tabular}


Table S7. Predicted Triplet Emission Maxima for 2 (CAM-B3LYP/6-31G*)

\begin{tabular}{|c|c|c|c|}
\hline Excited State \# & Wavlength (nm) & Oscillator Strength & MO Transitions (Configuration Interaction) \\
\hline 1 & 714.84 & 0 & $\begin{array}{l}167 \rightarrow 149(0.11705), 172 \rightarrow 151(0.10554) \\
161 \rightarrow 158(-0.15270), 161 \rightarrow 160(0.65103) \\
160 \rightarrow 161(0.16464)\end{array}$ \\
\hline 2 & 430.73 & 0 & 10 contributions to transition \\
\hline 3 & 356 & 0 & 13 contributions to transition \\
\hline 4 & 355.99 & 0 & 12 contributions to transition \\
\hline 5 & 352.41 & 0 & 14 contributions to transition \\
\hline 6 & 352.41 & 0 & 14 contributions to transition \\
\hline 7 & 311.38 & 0 & $\begin{array}{l}161 \rightarrow 144(0.16888), 161 \rightarrow 148(0.16617), \\
161 \rightarrow 149(0.10257), 161 \rightarrow 156(0.18648), \\
161 \rightarrow 158(0.32500), 162 \rightarrow 159(0.27949), \\
166 \rightarrow 159(0.11728), 163 \rightarrow 160(-0.13804), \\
175 \rightarrow 160(-0.22498)\end{array}$ \\
\hline 8 & 302.8 & 0 & $\begin{array}{l}161 \rightarrow 149(0.36471) 167 \rightarrow 158(-0.13996) \\
167 \rightarrow 160(0.51272)\end{array}$ \\
\hline 9 & 300.11 & 0 & $\begin{array}{l}162 \rightarrow 149(-0.10751), 161 \rightarrow 151(0.62727) \\
172 \rightarrow 160(0.14498)\end{array}$ \\
\hline 10 & 295.49 & 0 & $\begin{array}{l}163 \rightarrow 159(0.17437), 165 \rightarrow 159(0.25256), \\
174 \rightarrow 159(0.20474), 162 \rightarrow 160(-0.23373), \\
166 \rightarrow 160(0.29143), 173 \rightarrow 160(0.23323)\end{array}$ \\
\hline
\end{tabular}


a)

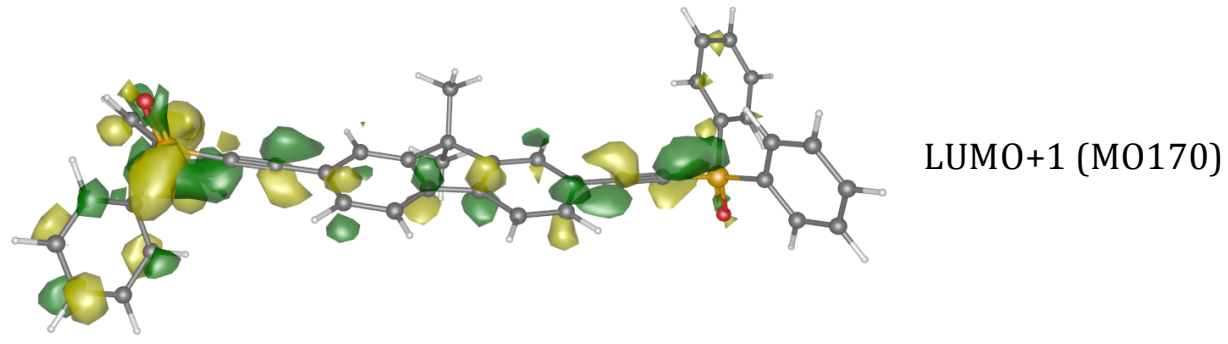

b)

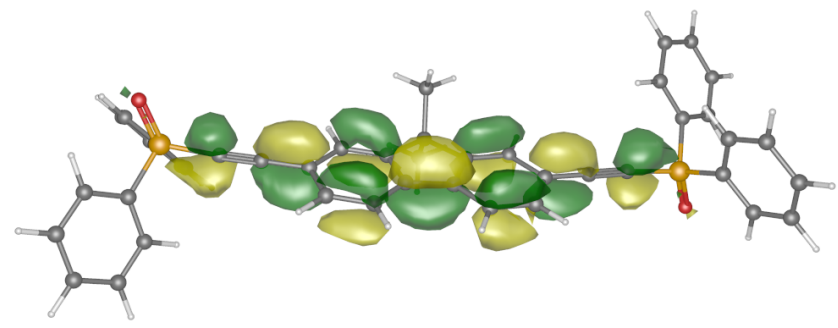

c)

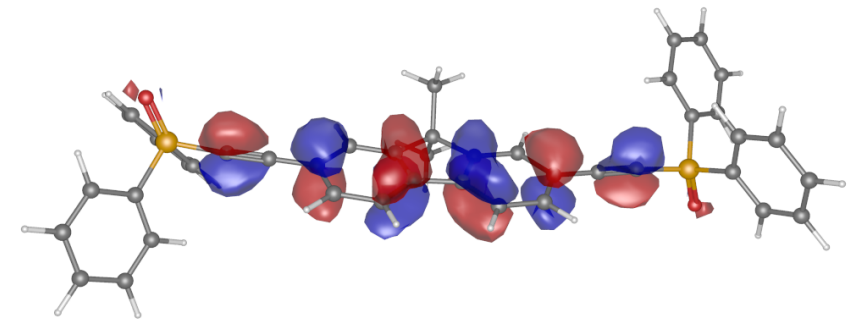

HOMO (M0168)

d)

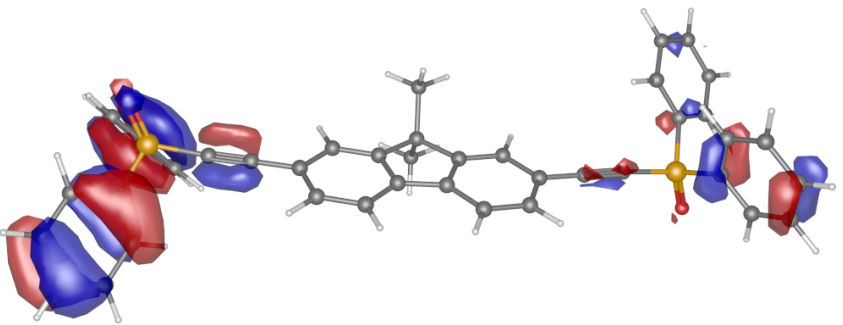

HOMO-1 (M0167)

Figure S23. a) LUMO+1 (MO 170), b) LUMO (M0169), c) HOMO (M0168), d) HOMO-1 (M0167) of ground state phosphine $2 \cdot(0)_{2}$. 
Table S8. Predicted Singlet Absorption Maxima for 2·(0) 2 (CAM-B3LYP/6-31G*)

\begin{tabular}{|c|c|c|c|}
\hline $\begin{array}{l}\text { Excited } \\
\text { State \# }\end{array}$ & $\begin{array}{l}\text { Wavelength } \\
(\mathrm{nm})\end{array}$ & $\begin{array}{l}\text { Oscillator } \\
\text { Strength }\end{array}$ & MO Transitions (Configuration Interaction) \\
\hline 1 & 316.88 & 1.9494 & $168 \rightarrow 169(0.68296)$ \\
\hline 2 & 259.18 & 0.0329 & $159 \rightarrow 169$ (0.49809), $168 \rightarrow 175$ (0.43160) \\
\hline 3 & 258.48 & 0.0357 & $\begin{array}{c}159 \rightarrow 172(-0.11811), 160 \rightarrow 175(-0.11510), 163 \rightarrow 169(0.50522), \\
164 \rightarrow 169(-0.28774), 168 \rightarrow 180(-0.28322)\end{array}$ \\
\hline 4 & 245.47 & 0.0415 & $\begin{array}{c}157 \rightarrow 169(0.14408), 160 \rightarrow 169(0.39375), 162 \rightarrow 169(-0.14385) \\
168 \rightarrow 170(-0.28842), 168 \rightarrow 172(0.31789)\end{array}$ \\
\hline 5 & 240.46 & 0.0025 & $\begin{array}{c}151 \rightarrow 169(-0.22980), 152 \rightarrow 170(-0.14568), 152 \rightarrow 172(0.17353), \\
153 \rightarrow 169(0.30276), 155 \rightarrow 169(-0.14048), 156 \rightarrow 169(0.19982) \\
166 \rightarrow 169(0.21535), 167 \rightarrow 169(0.20775)\end{array}$ \\
\hline 6 & 239.79 & 0.0008 & 10 contributions to transition \\
\hline 7 & 229.19 & 0.0006 & 14 contributions to transition \\
\hline 8 & 229.13 & 0.0023 & 10 contributions to transition \\
\hline 9 & 228.1 & 0.0109 & 14 contributions to transition \\
\hline 10 & 227.74 & 0.0225 & 12 contributions to transition \\
\hline
\end{tabular}

Table S9. Predicted Triplet Absorption Maxima for 2·(O) 2 (CAM-B3LYP/6-31G*)

\begin{tabular}{|c|c|c|c|}
\hline $\begin{array}{l}\text { Excited } \\
\text { State \# }\end{array}$ & $\begin{array}{c}\text { Wavelength } \\
\text { (nm) }\end{array}$ & $\begin{array}{l}\text { Oscillator } \\
\text { Strength }\end{array}$ & M0 Transitions (Configuration Interaction) \\
\hline 1 & 523.1 & 0 & $\begin{aligned} 159 & \rightarrow 175(-0.16245), 160 \rightarrow 170(-0.10572), 160 \rightarrow 172(0.13565), \\
163 & \rightarrow 180(0.12460), 168 \rightarrow 169(0.62760), 169 \rightarrow 168(0.12540)\end{aligned}$ \\
\hline 2 & 387.15 & 0 & $\begin{array}{c}157 \rightarrow 169(0.14936), 159 \rightarrow 180(-0.18337), \\
160 \rightarrow 169(0.38513), 162 \rightarrow 169(-0.13243), 163 \rightarrow 175(0.17983), 164 \rightarrow 175 \\
(-0.10367), 168 \rightarrow 170(-0.24160), \\
168 \rightarrow 172(0.30730), 168 \rightarrow 173(0.10413)\end{array}$ \\
\hline 3 & 359.16 & 0 & 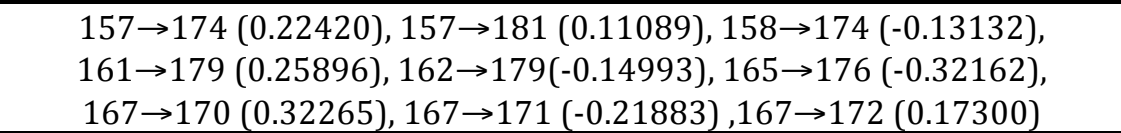 \\
\hline 4 & 358.08 & 0 & 10 contributions to transition \\
\hline 5 & 355.08 & 0 & 10 contributions to transition \\
\hline 6 & 354.27 & 0 & 10 contributions to transition \\
\hline 7 & 304.08 & 0 & $\begin{aligned} 159 & \rightarrow 170(0.12007), 159 \rightarrow 172(-0.15673), 159 \rightarrow 180(-0.12012), \\
159 & \rightarrow 184(0.11320), 163 \rightarrow 169(0.53449), 164 \rightarrow 169(-0.30619)\end{aligned}$ \\
\hline 8 & 300.5 & 0 & $\begin{aligned} & 159 \rightarrow 169(0.59271), 159 \rightarrow 175(0.11848), 163 \rightarrow 170(0.10820), \\
& 163 \rightarrow 172(-0.13927), 163 \rightarrow 180(-0.11194), 168 \rightarrow 175(-0.15616)\end{aligned}$ \\
\hline 9 & 290.38 & 0 & $\begin{aligned} 150 \rightarrow 169(-0.14280), 159 & \rightarrow 175(0.39673), 163 \rightarrow 180(-0.30008), \\
164 \rightarrow 180(0.17474), 168 & \rightarrow 169(0.16588), 168 \rightarrow 175(0.26165), \\
168 & \rightarrow 183(-0.11479)\end{aligned}$ \\
\hline 10 & 287.99 & 0 & $\begin{array}{l}159 \rightarrow 172(-0.10355), 159 \rightarrow 180(0.35064), 160 \rightarrow 169(0.16692), \\
163 \rightarrow 175(-0.38205), 164 \rightarrow 175(0.21885), 168 \rightarrow 180(0.14585)\end{array}$ \\
\hline
\end{tabular}


a)

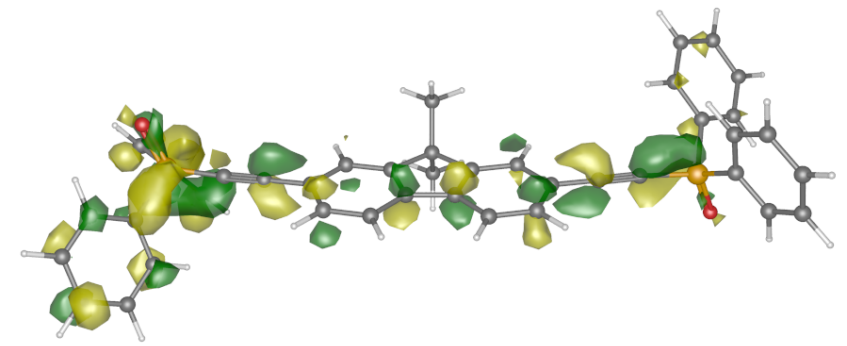

LUM0+1 (M0170)

b)

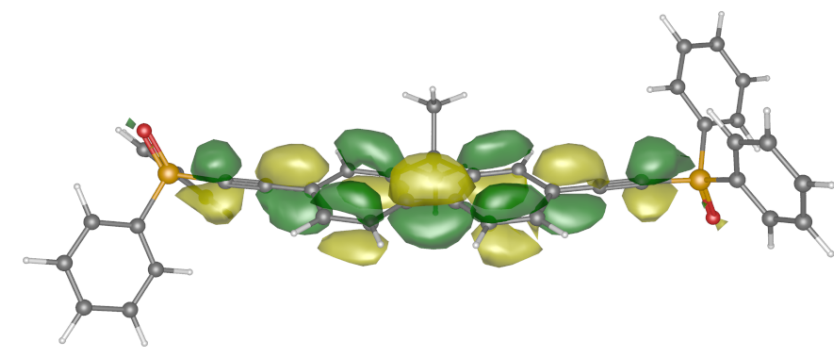

LUMO (M0169)

c)

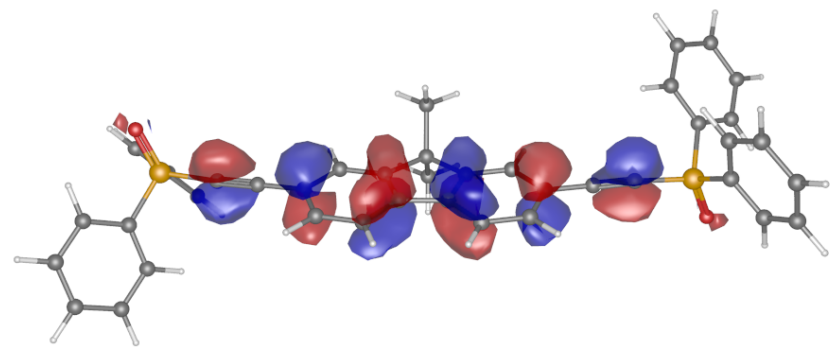

HOMO (M0168)

d)

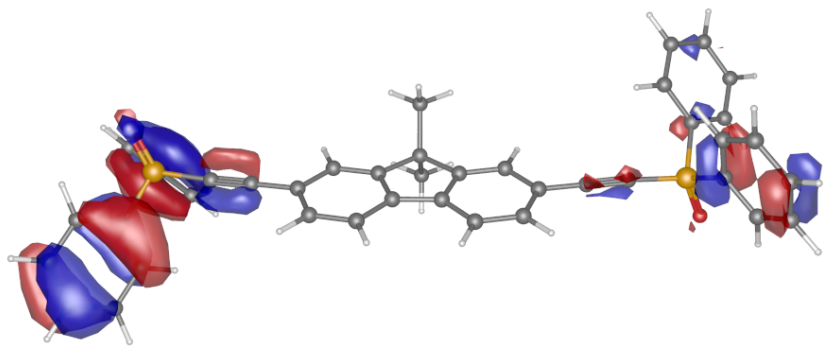

HOMO-1 (M0167)

Figure S24. a) LUMO+1 (MO 170), b) LUMO (M0169), c) HOMO (M0168), d) HOMO-1 (M0167) after geometry optimization of the first singlet excited state phosphine $\mathbf{2} \cdot(0)_{2}$. 
Table S10. Predicted Singlet Emission Maxima for $2 \cdot(0)_{2}\left(\mathrm{CAM}-\mathrm{B} 3 \mathrm{LYP} / 6-31 \mathrm{G}^{*}\right.$ )

\begin{tabular}{|c|c|c|c|}
\hline $\begin{array}{l}\text { Excited } \\
\text { State \# }\end{array}$ & $\begin{array}{r}\text { Wavelength } \\
\text { (nm) }\end{array}$ & $\begin{array}{r}\text { Oscillator } \\
\text { Strength }\end{array}$ & MO Transitions (Configuration Interaction) \\
\hline 1 & 368.3 & 1.9844 & $169 \rightarrow 168(0.69080)$ \\
\hline 2 & 267.46 & 0.0348 & $169 \rightarrow 160(0.59546), 170 \rightarrow 168(0.10060), 180 \rightarrow 168(0.26993)$ \\
\hline 3 & 267.31 & 0.0158 & $\begin{array}{l}169 \rightarrow 157(-0.12224), 169 \rightarrow 158(0.47401), 169 \rightarrow 159(0.13001) \\
175 \rightarrow 168(-0.43672)\end{array}$ \\
\hline 4 & 258.25 & 0.043 & $\begin{array}{l}169 \rightarrow 161(-0.23151), 169 \rightarrow 163(-0.30502), 169 \rightarrow 166(0.17220), \\
169 \rightarrow 167(-0.23062), 170 \rightarrow 168(0.31230), 171 \rightarrow 168(- \\
0.10775), 172 \rightarrow 168(-0.18850)\end{array}$ \\
\hline 5 & 251.83 & 0.0023 & $\begin{array}{l}170 \rightarrow 151(-0.15963), 172 \rightarrow 151(0.11585), 169 \rightarrow 153 \\
(0.41239), 169 \rightarrow 155(-0.11543), 169 \rightarrow 156(0.21387), 169 \rightarrow 161 \\
(0.10350), 169 \rightarrow 162(0.11377), 169 \rightarrow 163(0.10407), 169 \rightarrow 167 \\
(-0.25715)\end{array}$ \\
\hline 6 & 250.7 & 0.0014 & $\begin{array}{l}169 \rightarrow 151(0.38034), 169 \rightarrow 152(0.16453), 170 \rightarrow 153- \\
(0.17434), 172 \rightarrow 153(0.11958), 169 \rightarrow 155(0.21693) \\
169 \rightarrow 161(-0.11024), 169 \rightarrow 166(-0.28593)\end{array}$ \\
\hline 7 & 238.51 & 0.0065 & $\begin{array}{l}173 \rightarrow 161(-0.11610), 173 \rightarrow 163(-0.14485), 181 \rightarrow 163 \\
(0.11636), 172 \rightarrow 168(0.26314), 173 \rightarrow 168(0.34041), 174 \rightarrow 168 \\
(0.18465), 181 \rightarrow 168(-0.23043), 182 \rightarrow 168(-0.13129)\end{array}$ \\
\hline 8 & 236.73 & 0.0027 & $\begin{array}{l}174 \rightarrow 161(0.12818), 182 \rightarrow 161(-0.10510), 174 \rightarrow 163 \\
(0.16804), 182 \rightarrow 163(-0.12576), 173 \rightarrow 168(-0.22408) \\
174 \rightarrow 168(0.40698), 181 \rightarrow 168(0.10167), 182 \rightarrow 168(-0.24062), \\
183 \rightarrow 168(-0.10370)\end{array}$ \\
\hline 9 & 234.04 & 0.0135 & 10 contributions to transition \\
\hline 10 & 228.1 & 0.1774 & $\begin{array}{l}169 \rightarrow 150(-0.10548), 169 \rightarrow 158(0.38357), 169 \rightarrow 159(0.13476), \\
175 \rightarrow 168(0.49101)\end{array}$ \\
\hline
\end{tabular}


Table S11. Predicted Triplet Emission Maxima for 2·(0) ${ }_{2}$ (CAM-B3LYP/6-31G*)

\begin{tabular}{|c|c|c|c|}
\hline $\begin{array}{c}\text { Excited } \\
\text { State \# }\end{array}$ & $\begin{array}{r}\text { Wavelength } \\
\text { (nm) }\end{array}$ & $\begin{array}{l}\text { Oscillator } \\
\text { Strength }\end{array}$ & MO Transitions (Configuration Interaction) \\
\hline 1 & 704.78 & 0 & $\begin{array}{l}175 \rightarrow 158(0.11350) 180 \rightarrow 160(-0.11251), 169 \rightarrow 168 \\
(0.67255), 168 \rightarrow 169(0.17411)\end{array}$ \\
\hline 2 & 411.79 & 0 & 13 contributions to transition \\
\hline 3 & 353.73 & 0 & 11 contributions to transition \\
\hline 4 & 352.16 & 0 & 11 contributions to transition \\
\hline 5 & 349.65 & 0 & 10 contributions to transition \\
\hline 6 & 348.35 & 0 & $\begin{array}{l}170 \rightarrow 157(-0.22253), 171 \rightarrow 157(-0.17611), 172 \rightarrow 157(- \\
0.16489), 176 \rightarrow 161(0.20620), 176 \rightarrow 162(-0.23983), 179 \rightarrow 165 \\
(-0.31179), 174 \rightarrow 166(-0.14384), 174 \rightarrow 167(-0.25995), \\
182 \rightarrow 167(-0.12945)\end{array}$ \\
\hline 7 & 313.58 & 0 & $170 \rightarrow 158(0.12694), 169 \rightarrow 160(0.64739)$ \\
\hline 8 & 308.54 & 0 & $\begin{array}{l}169 \rightarrow 157(-0.14475), 169 \rightarrow 158(0.57701), 169 \rightarrow 159 \\
(0.16091), 170 \rightarrow 160(0.14204), 172 \rightarrow 160(-0.10583), \\
175 \rightarrow 168(0.18957)\end{array}$ \\
\hline 9 & 289.85 & 0 & $\begin{array}{l}169 \rightarrow 150(0.32634), 182 \rightarrow 153(-0.10825), 169 \rightarrow 154 \\
(0.21099), 170 \rightarrow 161(0.11249) 170 \rightarrow 163(0.14251), 175 \rightarrow 168 \\
(0.12583), 181 \rightarrow 168(0.13032), 183 \rightarrow 168(0.20676)\end{array}$ \\
\hline 10 & 284.64 & 0 & $\begin{array}{l}169 \rightarrow 158(-0.13765), 175 \rightarrow 158(-0.24001), 180 \rightarrow 160 \\
(0.22470), 169 \rightarrow 168(0.11789), 175 \rightarrow 168(0.55488)\end{array}$ \\
\hline
\end{tabular}


a)

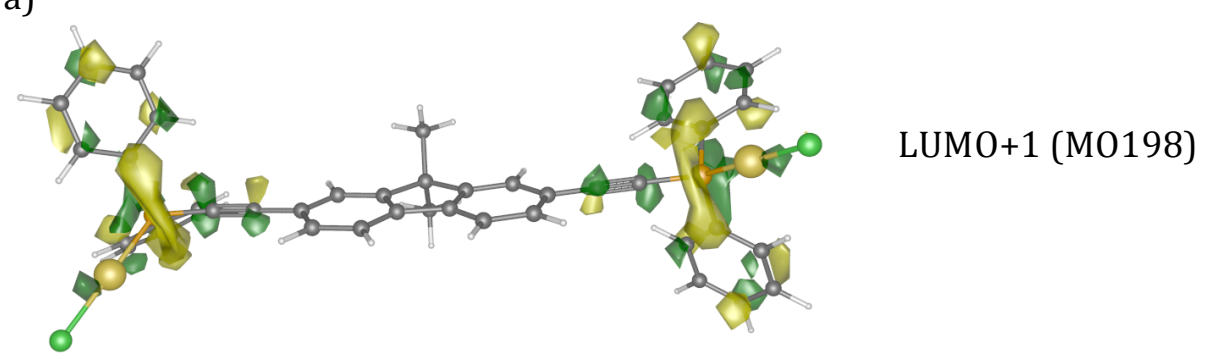

b)

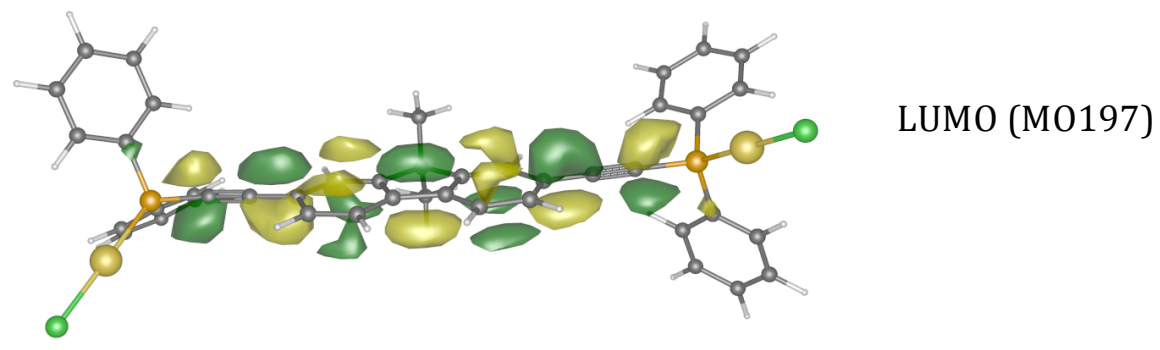

c)

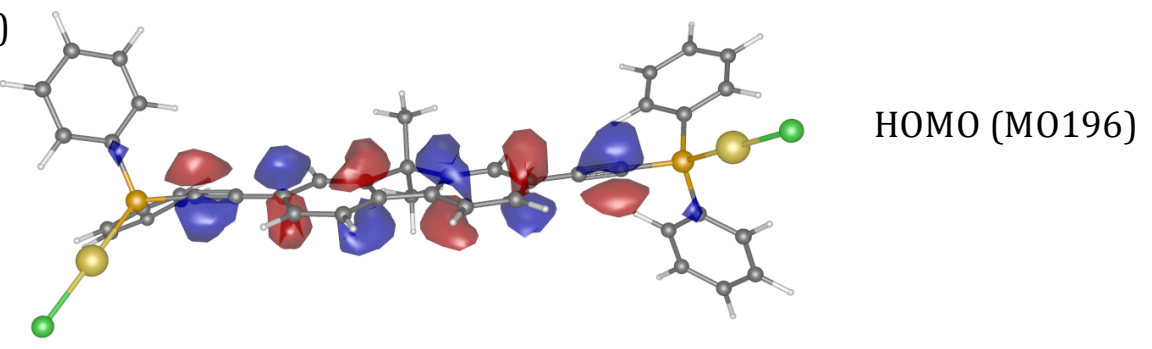

d)

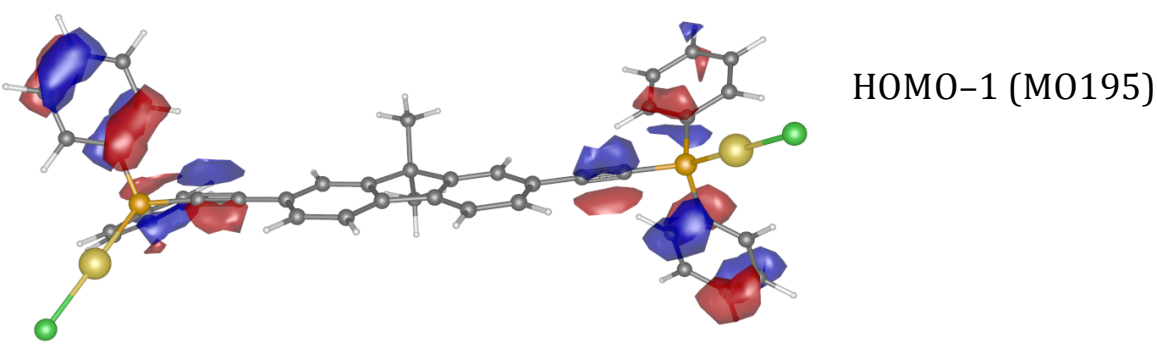

Figure S25. a) LUMO+1 (MO 198), b) LUMO (M0197), c) HOMO (M0196), d) HOMO-1 (M0195) of phosphine $2 \cdot(\mathrm{AuCl})_{2}$ 
Table S12. Predicted Singlet Absorption Maxima for 2·(AuCl) 2 [(CAM-B3LYP/6$\left.31 \mathrm{G}^{*}(\mathrm{C}, \mathrm{H}, \mathrm{P}, \mathrm{Cl}), \mathrm{LANL} 2 \mathrm{DZ}(\mathrm{Au})\right]$

\begin{tabular}{|c|c|c|c|}
\hline $\begin{array}{r}\text { Excited State } \\
\#\end{array}$ & $\begin{array}{r}\text { Wavelength } \\
\text { (nm) }\end{array}$ & $\begin{array}{r}\text { Oscillator } \\
\text { Strength }\end{array}$ & $\begin{array}{c}\text { M0 Transitions (Configuration } \\
\text { Interaction) }\end{array}$ \\
\hline 1 & 312.2 & 1.9812 & $196 \rightarrow 197(0.67574)$ \\
\hline 2 & 255.9 & 0.0237 & $\begin{array}{l}186 \rightarrow 197(0.23621), 187 \rightarrow 197(- \\
0.17999) 189 \rightarrow 197(-0.32166), 191 \rightarrow 197 \\
(-0.10825), 196 \rightarrow 201(0.43831) \\
196 \rightarrow 206(0.15180)\end{array}$ \\
\hline 3 & 254.45 & 0.0342 & $\begin{array}{l}192 \rightarrow 197(0.55783), 195 \rightarrow 197(0.13122) \\
196 \rightarrow 211(0.16262), 196 \rightarrow 212(- \\
0.24865)\end{array}$ \\
\hline 4 & 252.72 & 0.003 & $\begin{array}{l}193 \rightarrow 197(-0.21615), 195 \rightarrow 197(- \\
0.30615), 196 \rightarrow 198(0.38900), 196 \rightarrow 200( \\
0.17872)\end{array}$ \\
\hline 5 & 241.65 & 0.1086 & 10 contributions to transition \\
\hline 6 & 235.77 & 0.0127 & $\begin{array}{l}193 \rightarrow 197(-0.15969), 193 \rightarrow 199(- \\
0.10940), 195 \rightarrow 197(-0.14611) 195 \rightarrow 199 \\
(-0.19110), 196 \rightarrow 198(-0.25917), \\
196 \rightarrow 200(0.30545), 196 \rightarrow 202(0.23014), \\
196 \rightarrow 209(0.15246), 196 \rightarrow 215(0.13171)\end{array}$ \\
\hline 7 & 234.55 & 0.0002 & 10 contributions to transition \\
\hline 8 & 234.2 & 0.0529 & 10 contributions to transition \\
\hline 9 & 230.68 & 0.0049 & $\begin{array}{l}186 \rightarrow 208(0.11279), 187 \rightarrow 199(0.16396), \\
188 \rightarrow 198(0.20416), 190 \rightarrow 198(0.27009), \\
191 \rightarrow 197(0.14173), 191 \rightarrow 199(- \\
0.23948), 191 \rightarrow 206(-0.10632), 195 \rightarrow 202 \\
(0.13656), 195 \rightarrow 207(0.10503)\end{array}$ \\
\hline 10 & 230.58 & 0.0017 & $\begin{array}{l}186 \rightarrow 207(0.10723), 187 \rightarrow 198(- \\
0.19921), 188 \rightarrow 197(0.11401), 188 \rightarrow 199 \\
(-0.14026), 190 \rightarrow 197(0.10908) \\
190 \rightarrow 199(-0.24522), 191 \rightarrow 198 \\
(0.27442), 195 \rightarrow 199(-0.10656) \\
195 \rightarrow 208(0.14038)\end{array}$ \\
\hline
\end{tabular}


Table S13. Predicted Triplet Absorption Maxima for 2 $(\mathrm{AuCl})_{2}$ [(CAM-B3LYP/6-

$31 \mathrm{G}^{*}(\mathrm{C}, \mathrm{H}, \mathrm{P}, \mathrm{Cl})$, LANL2DZ $\left.(\mathrm{Au})\right]$

\begin{tabular}{|r|r|r|l|}
\hline $\begin{array}{r}\text { Excited } \\
\text { State \# }\end{array}$ & $\begin{array}{r}\text { Wavelength } \\
\mathbf{( n m})\end{array}$ & $\begin{array}{r}\text { Oscillator } \\
\text { Strength }\end{array}$ & \multicolumn{1}{|c|}{ MO Transitions (Configuration Interaction) } \\
\hline 1 & 494.61 & 0 & $\begin{array}{l}189 \rightarrow 203(0.10170), 192 \rightarrow 212(0.12314), \\
196 \rightarrow 197(0.60800), 196 \rightarrow 206(0.10564), \\
197 \rightarrow 196(0.11129)\end{array}$ \\
\hline 2 & 377.03 & 0 & 10 contributions to transition \\
\hline 3 & 353.96 & 0 & 14 contributions to transition \\
\hline 4 & 353.61 & 0 & 14 contributions to transition \\
\hline 5 & 349.96 & 0 & 11 contributions to transition \\
\hline 6 & 349.96 & 0 & 12 contributions to transition \\
\hline 7 & 298.41 & 0 & $189 \rightarrow 212(-0.10380), 192 \rightarrow 197(0.57028)$, \\
\hline 8 & 294.74 & 0 & 11 contributions to transition \\
\hline 9 & 290.61 & 0 & 10 contributions to transition \\
\hline 10 & 285.78 & 0 & 11 contributions to transition \\
\hline & & &
\end{tabular}


a)

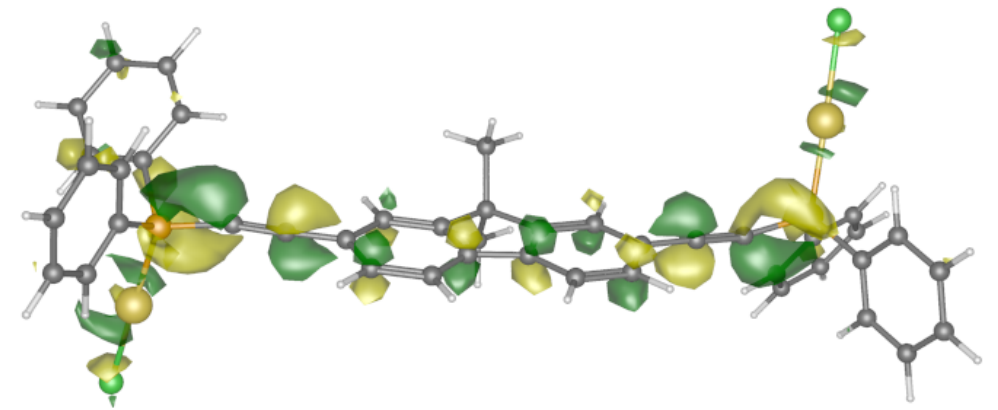

LUMO+1 (M0198)

b)

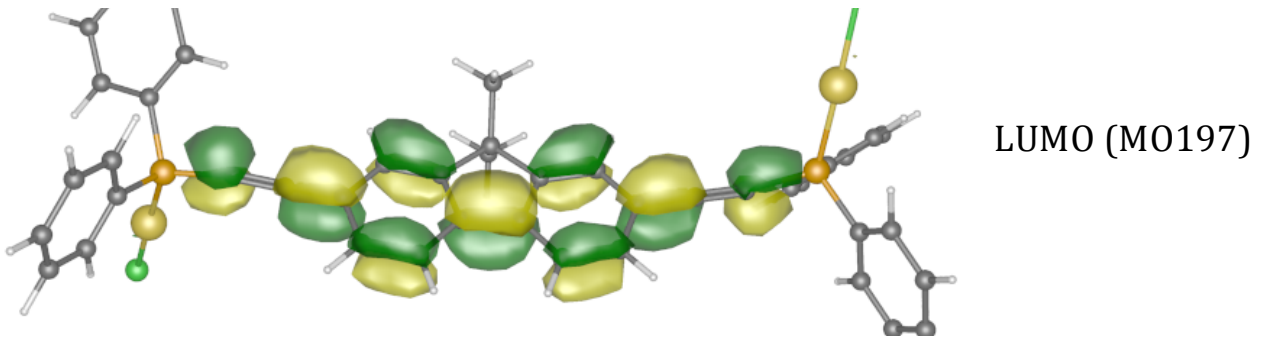

c)

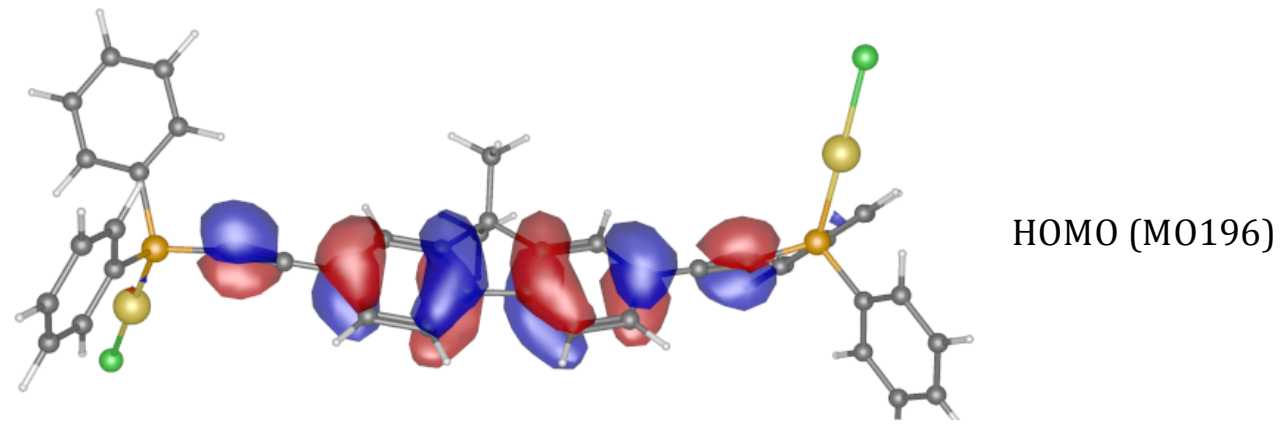

d)

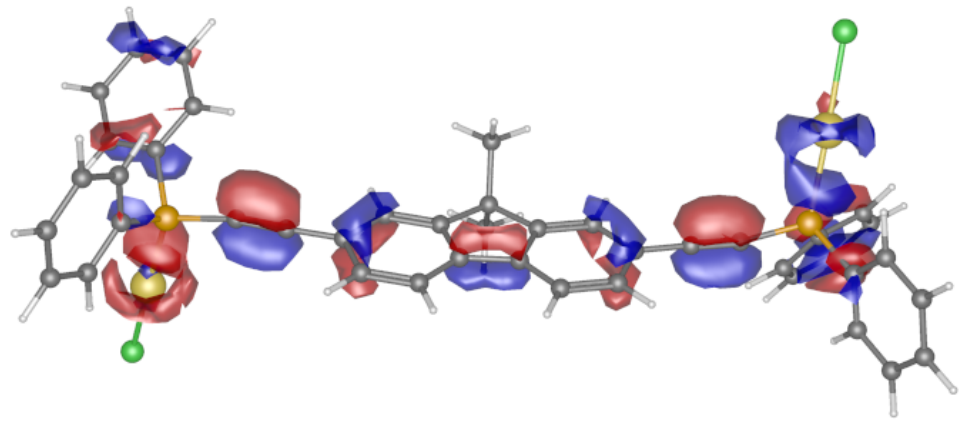

HOMO-1 (M0195)

Figure S26. a) LUMO+1 (MO 198), b) LUMO (M0197), c) HOMO (M0196), d) HOMO-1 (M0195) after geometry optimization of the first singlet excited state of $\mathbf{2} \cdot(\mathrm{AuCl})_{2}$ 
Table S14. Predicted Singlet Emission Maxima for 2 $(\mathrm{AuCl})_{2}[(\mathrm{CAM}-\mathrm{B} 3 \mathrm{LYP} / 6$ $\left.31 \mathrm{G}^{*}(\mathrm{C}, \mathrm{H}, \mathrm{P}, \mathrm{Cl}), \mathrm{LANL} 2 \mathrm{DZ}(\mathrm{Au})\right]$

\begin{tabular}{|c|c|c|c|}
\hline Excited State \# & Wavelength (nm) & Oscillator Strength & $\begin{array}{l}\text { M0 Transitions (Configuration } \\
\text { Interaction) }\end{array}$ \\
\hline 1 & 381.25 & 2.2588 & $\begin{array}{l}198 \rightarrow 195(-0.10476) \\
197 \rightarrow 196(0.68465)\end{array}$ \\
\hline 2 & 279.73 & 0.0352 & $\begin{array}{l}197 \rightarrow 192(0.10442), 197 \rightarrow 193 \\
(0.17278), 197 \rightarrow 195(0.41720) \\
198 \rightarrow 196(-0.40756) \\
202 \rightarrow 196(0.12690)\end{array}$ \\
\hline 3 & 270.57 & 0.0266 & $\begin{array}{l}197 \rightarrow 182(-0.13571), \\
197 \rightarrow 184(0.15825), \\
197 \rightarrow 185(0.35296), \\
197 \rightarrow 187(-0.19735), 197 \rightarrow 192 \\
(0.25016), 198 \rightarrow 192(-0.10232), \\
203 \rightarrow 196(0.12027), 206 \rightarrow 196 \\
(0.34397), 213 \rightarrow 196(0.10143)\end{array}$ \\
\hline 4 & 270.51 & 0.0521 & $\begin{array}{l}197 \rightarrow 185(-0.16499), 197 \rightarrow 192 \\
(0.53231), 197 \rightarrow 195(-0.10615) \\
206 \rightarrow 196(-0.15738) 213 \rightarrow 196 \\
(0.21868)\end{array}$ \\
\hline 5 & 267.46 & 0.0129 & $\begin{array}{l}200 \rightarrow 193(-0.12016), 200 \rightarrow 195(- \\
0.25974), 216 \rightarrow 195(0.12287) \\
199 \rightarrow 196(0.22906), 200 \rightarrow 196 \\
(0.42671), 204 \rightarrow 196(-0.12526), \\
216 \rightarrow 196(-0.17193)\end{array}$ \\
\hline 6 & 266.61 & 0.012 & $\begin{array}{l}199 \rightarrow 193(0.11034), 199 \rightarrow 195 \\
(0.26758), 215 \rightarrow 195(-0.12392), 199 \\
\rightarrow 196(0.42376), 200 \rightarrow 196(- \\
0.23511), 205 \rightarrow 196(-0.10268), \\
215 \rightarrow 196(-0.18115), 216 \rightarrow 196 \\
(0.10241)\end{array}$ \\
\hline 7 & 251.77 & 0.0113 & 11 contributions to transition \\
\hline 8 & 249.19 & 0.0022 & $\begin{array}{l}197 \rightarrow 176(0.22533), 197 \rightarrow 177 \\
(0.39104), 198 \rightarrow 177(0.21136), 197 \\
\rightarrow 182(0.13971), 197 \rightarrow 187(- \\
0.12487), 197 \rightarrow 193(-0.11207) \\
198 \rightarrow 193(-0.10256), 197 \rightarrow 194(- \\
0.20654)\end{array}$ \\
\hline 9 & 245.94 & 0.0081 & $\begin{array}{l}197 \rightarrow 193(0.10014), 197 \rightarrow 195 \\
(0.42402), 198 \rightarrow 196(0.46645)\end{array}$ \\
\hline 10 & 242.09 & 0.0837 & $\begin{array}{l}197 \rightarrow 176(-0.12829), 197 \rightarrow 177 \\
(0.11835), 197 \rightarrow 180(0.12261), \\
197 \rightarrow 187(-0.10772), 197 \rightarrow 194 \\
(0.33774), 198 \rightarrow 195(-0.32719) \\
201 \rightarrow 196(-0.21522), 206 \rightarrow 196(- \\
0.16492)\end{array}$ \\
\hline
\end{tabular}


Table S15. Predicted Triplet Emission Maxima for 2 $(\mathrm{AuCl})_{2}$ [(CAM-B3LYP/6-

$31 \mathrm{G}^{*}(\mathrm{C}, \mathrm{H}, \mathrm{P}, \mathrm{Cl})$, LANL2DZ $\left.(\mathrm{Au})\right]$

\begin{tabular}{|c|c|c|c|}
\hline $\begin{array}{r}\text { Excited } \\
\text { State \# }\end{array}$ & $\begin{array}{r}\text { Wavelength } \\
\text { (nm) }\end{array}$ & $\begin{array}{r}\text { Oscillator } \\
\text { Strength }\end{array}$ & MO Transitions (Configuration Interaction) \\
\hline 1 & 717.51 & 0 & $\begin{array}{l}213 \rightarrow 192(-0.10194), 198 \rightarrow 195(-0.12183), 197 \rightarrow 196(0.65666) \\
196 \rightarrow 197(0.16843)\end{array}$ \\
\hline 2 & 436.96 & 0 & $\begin{array}{l}197 \rightarrow 175(-0.11661), 197 \rightarrow 181(0.15144), 206 \rightarrow 192(-0.11774), \\
197 \rightarrow 193(0.21861), 197 \rightarrow 195(0.37555), 198 \rightarrow 196(-0.35488), \\
202 \rightarrow 196(0.16037), 207 \rightarrow 196(-0.13086), 214 \rightarrow 196(0.10852)\end{array}$ \\
\hline 3 & 360.47 & 0 & 14 contributions to transition \\
\hline 4 & 360.21 & 0 & 15 contributions to transition \\
\hline 5 & 359.32 & 0 & 12 contributions to transition \\
\hline 6 & 359.18 & 0 & 14 contributions to transition \\
\hline 7 & 318.72 & 0 & $198 \rightarrow 185(-0.11775), 197 \rightarrow 192(0.63365)$ \\
\hline 8 & 314.22 & 0 & $\begin{array}{l}197 \rightarrow 182(-0.13642), 197 \rightarrow 184(0.18009), 197 \rightarrow 185(0.44184), \\
197 \rightarrow 187(-0.27047), 198 \rightarrow 192(-0.15298), 198 \rightarrow 195(-0.11044), \\
206 \rightarrow 196(-0.14312)\end{array}$ \\
\hline 9 & 306.02 & 0 & 12 contributions to transition \\
\hline 10 & 291.81 & 0 & $\begin{array}{l}197 \rightarrow 177(0.14683), 197 \rightarrow 178(-0.15649), 199 \rightarrow 195(0.14099), \\
200 \rightarrow 195(-0.17347), 216 \rightarrow 195(0.10813), 199 \rightarrow 196(0.32085), \\
200 \rightarrow 196(0.15704) 204 \rightarrow 196(-0.10042), 215 \rightarrow 196(-0.17441)\end{array}$ \\
\hline
\end{tabular}


a)

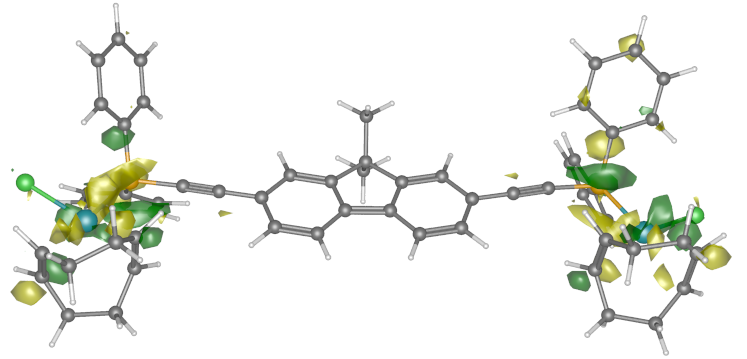

b)

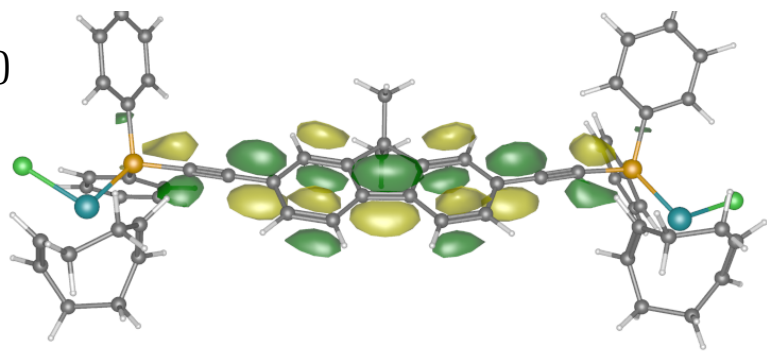

c)

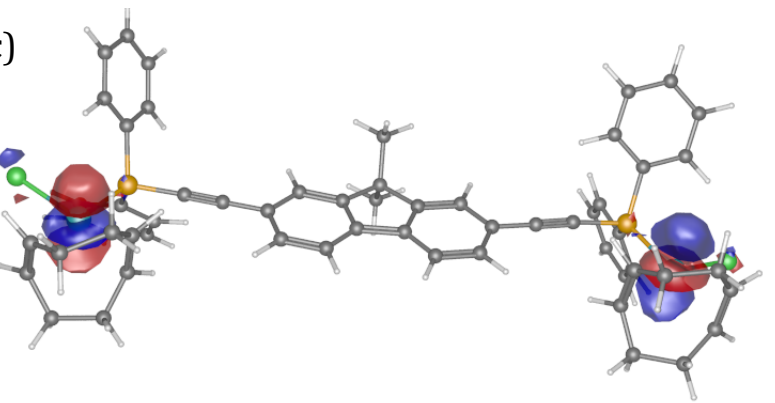

d)

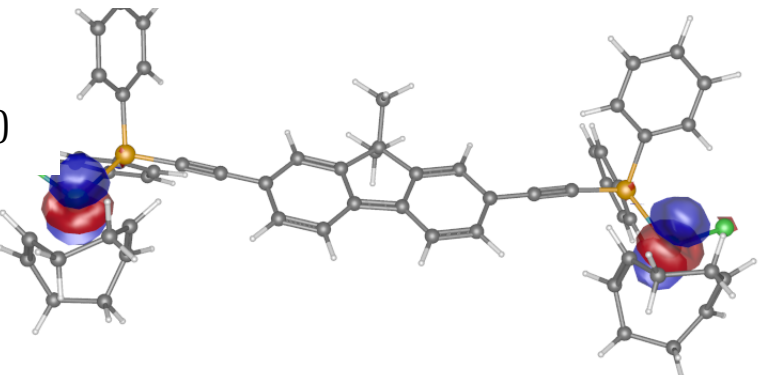

e)

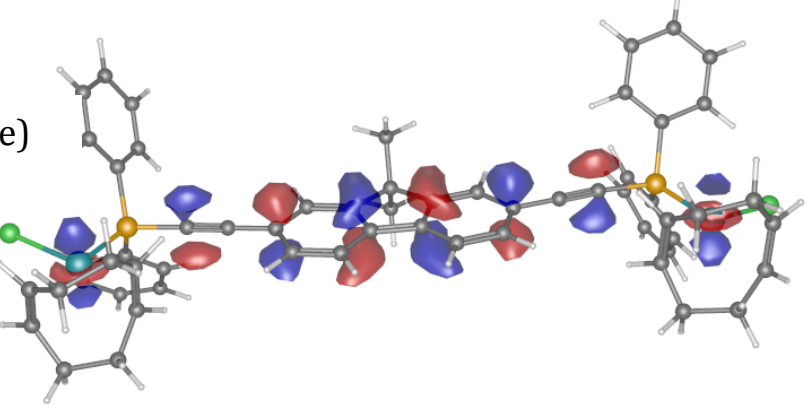

\section{LUMO+1 (MO256)}

LUMO (M0255)

HOMO (MO254)

HOMO-1 (MO253)

HOMO-2 (MO252)

Figure S27. a) LUMO+1 (MO 256), b) LUMO (M0255), c) HOMO (MO254), d) HOMO-1 (MO 253), e) HOMO-2 (MO252) of 2·[Rh(COD)Cl $]_{2}$ 
Table S16. Predicted Singlet Absorption Maxima for 2·[Rh(COD)Cl $]_{2}[(\mathrm{CAM}-\mathrm{B} 3 \mathrm{LYP} / 6-$ $\left.31 \mathrm{G}^{*}(\mathrm{C}, \mathrm{H}, \mathrm{P}, \mathrm{Cl}), \mathrm{LANL} 2 \mathrm{DZ}(\mathrm{Rh})\right]$

\begin{tabular}{|c|c|c|c|}
\hline $\begin{array}{r}\text { Excited } \\
\text { State \# }\end{array}$ & $\begin{array}{r}\text { Wavelength } \\
(\mathrm{nm})\end{array}$ & $\begin{array}{r}\text { Oscillator } \\
\text { Strength }\end{array}$ & MO Transitions (Configuration Interaction) \\
\hline 1 & 447.82 & 0.0062 & $\begin{array}{l}252 \rightarrow 257(0.13952), 252 \rightarrow 259(0.11644), 253 \rightarrow 256(- \\
0.21858), 253 \rightarrow 258(0.36727), 253 \rightarrow 260(0.12805) \\
253 \rightarrow 263(0.10047), 254 \rightarrow 257(0.31573), 254 \rightarrow 259 \\
(0.25554), 254 \rightarrow 264(0.13498)\end{array}$ \\
\hline 2 & 447.78 & 0.0061 & $\begin{array}{l}252 \rightarrow 258(0.14972), 253 \rightarrow 257(0.34499), 253 \rightarrow 259 \\
(0.28031), 253 \rightarrow 264(0.14837), 254 \rightarrow 256(-0.19967), \\
254 \rightarrow 258(0.33570) 254 \rightarrow 260(0.11623)\end{array}$ \\
\hline 3 & 367.15 & 0.0011 & 11 contributions to transition \\
\hline 4 & 367.15 & 0.0033 & 11 contributions to transition \\
\hline 5 & 355.79 & 0.026 & 11 contributions to transition \\
\hline 6 & 355.78 & 0.0019 & 12 contributions to transition \\
\hline 7 & 339.26 & 0.0006 & 13 contributions to transition \\
\hline 8 & 339.24 & 0.033 & 13 contributions to transition \\
\hline 9 & 337.37 & 0.012 & $\begin{array}{l}246 \rightarrow 257(0.28606), 246 \rightarrow 259(0.21966), 246 \rightarrow 264 \\
(0.12283), 247 \rightarrow 256(0.18726), 247 \rightarrow 258(-0.29663), \\
248 \rightarrow 257(0.11910), 248 \rightarrow 259(0.11513), 249 \rightarrow 258 \\
(0.14319), 250 \rightarrow 257(0.14107), 251 \rightarrow 258(0.13770)\end{array}$ \\
\hline 10 & 337.35 & 0.0002 & $\begin{array}{l}246 \rightarrow 256(0.18794), 246 \rightarrow 258(-0.29727) 247 \rightarrow 257 \\
(0.28646), 247 \rightarrow 259(0.21865), 247 \rightarrow 264(0.12277), \\
248 \rightarrow 258(-0.14300), 249 \rightarrow 257(-0.11870), 249 \rightarrow 259(- \\
0.11454), 250 \rightarrow 258(-0.13738), 251 \rightarrow 257(-0.14085)\end{array}$ \\
\hline 11 & 319.22 & 2.1238 & $252 \rightarrow 255(0.60500), 254 \rightarrow 255(-0.30230)$ \\
\hline 12 & 282.81 & 0.010 & $\begin{array}{l}248 \rightarrow 256(0.19624), 248 \rightarrow 260(0.10948), 249 \rightarrow 257(- \\
0.16870), 249 \rightarrow 259(0.14566), 250 \rightarrow 256(-0.27007), \\
250 \rightarrow 260(-0.16844), 251 \rightarrow 255(0.12066), 251 \rightarrow 257 \\
(0.21984), 251 \rightarrow 259(-0.23057)\end{array}$ \\
\hline
\end{tabular}


Table S17. Predicted Triplet Absorption Maxima for $\mathbf{2} \cdot[\mathrm{Rh}(\operatorname{cod}) \mathrm{Cl}]_{2}[(\mathrm{CAM}-\mathrm{B} 3 \mathrm{LYP} / 6-$ $31 \mathrm{G}^{*}(\mathrm{C}, \mathrm{H}, \mathrm{P}, \mathrm{Cl})$, LANL2DZ $\left.(\mathrm{Au})\right]$

\begin{tabular}{|c|c|c|c|}
\hline $\begin{array}{r}\text { Excited } \\
\text { State \# }\end{array}$ & Wavelength (nm) & $\begin{array}{r}\text { Oscillator } \\
\text { Strength }\end{array}$ & MO Transitions (Configuration Interaction) \\
\hline 1 & 631.00 & 0 & 12 contributions to transition \\
\hline 2 & 630.98 & 0 & $\begin{array}{l}252 \rightarrow 258(-0.11021), 253 \rightarrow 256(-0.14413), 253 \rightarrow 257(- \\
0.24494), 253 \rightarrow 258(0.25250), 253 \rightarrow 259(-0.20618), \\
253 \rightarrow 264(-0.11409), 254 \rightarrow 256(0.13927), 254 \rightarrow 257 \\
(0.21208), 254 \rightarrow 258(-0.24380), 254 \rightarrow 259(0.17813)\end{array}$ \\
\hline 3 & 522.01 & 0 & $\begin{array}{l}235 \rightarrow 262(0.13650), 237 \rightarrow 268(-0.11635), 252 \rightarrow 255 \\
(0.55900), 254 \rightarrow 255(-0.26140) 252 \rightarrow 255(0.11116)\end{array}$ \\
\hline 4 & 447.24 & 0 & $\begin{array}{l}250 \rightarrow 256(-0.13419) 250 \rightarrow 257(0.16328), 250 \rightarrow 258 \\
(0.25506), 250 \rightarrow 259(0.15055), 251 \rightarrow 256(-0.10368), \\
251 \rightarrow 257(0.22905), 251 \rightarrow 258(0.19722), 251 \rightarrow 259 \\
(0.21133), 251 \rightarrow 264(0.11133)\end{array}$ \\
\hline 5 & 447.24 & 0 & $\begin{array}{l}250 \rightarrow 256(-0.10359), 250 \rightarrow 257(-0.22935), 250 \rightarrow 258 \\
(0.19717), 250 \rightarrow 259(-0.21127), 250 \rightarrow 264(-0.11147) \\
251 \rightarrow 256(0.13385), 251 \rightarrow 257(0.16326), 251 \rightarrow 258(- \\
0.25496), 251 \rightarrow 259(0.15050)\end{array}$ \\
\hline 6 & 429.95 & 0 & $\begin{array}{l}246 \rightarrow 258(0.10832), 247 \rightarrow 258(-0.10683), 248 \rightarrow 257 \\
(0.14405), 248 \rightarrow 258(0.18586), 248 \rightarrow 259(0.14030), \\
249 \rightarrow 257(0.17447), 249 \rightarrow 258(0.19264), 249 \rightarrow 259 \\
(0.16996)\end{array}$ \\
\hline 7 & 429.93 & 0 & $\begin{array}{l}246 \rightarrow 257(-0.10027), 246 \rightarrow 258(0.10793), 247 \rightarrow 258 \\
(0.10700), 248 \rightarrow 257(-0.17476), 248 \rightarrow 258(0.19273), \\
248 \rightarrow 259(-0.17006), 249 \rightarrow 257(0.14389), 249 \rightarrow 258(- \\
0.18555), 249 \rightarrow 259(0.14005)\end{array}$ \\
\hline 8 & 419.75 & 0 & $\begin{array}{l}227 \rightarrow 258(0.11317) 228 \rightarrow 257(-0.10022) 246 \rightarrow 256 \\
(0.17556), 246 \rightarrow 258(-0.31096), 246 \rightarrow 260(-0.11060) \\
247 \rightarrow 257(0.28425), 247 \rightarrow 259(0.24233), 247 \rightarrow 264 \\
(0.13250), 248 \rightarrow 258(0.11315), 249 \rightarrow 257(0.12205)\end{array}$ \\
\hline 9 & 419.74 & 0 & $\begin{array}{l}227 \rightarrow 257(-0.10479), 228 \rightarrow 258(0.11005), 246 \rightarrow 257 \\
(0.28360), 246 \rightarrow 259(0.24129), 246 \rightarrow 264(0.13203), \\
247 \rightarrow 256(0.17595), 247 \rightarrow 258(-0.31226), 247 \rightarrow 260(- \\
0.11120), 248 \rightarrow 257(-0.12221), 249 \rightarrow 258(-0.11298)\end{array}$ \\
\hline 10 & 402.46 & 0 & $\begin{array}{l}252 \rightarrow 256(0.12805), 252 \rightarrow 260(0.11064), 253 \rightarrow 255(- \\
0.12057), 253 \rightarrow 257(-0.27949), 253 \rightarrow 259(0.34197) \\
253 \rightarrow 266(0.10948), 254 \rightarrow 256(0.31458), 254 \rightarrow 258 \\
(0.11130), 254 \rightarrow 260(0.23230), 254 \rightarrow 263(-0.11409)\end{array}$ \\
\hline
\end{tabular}




\section{References}

(1) Birks, J. B., Photophysics of Aromatic Molecules. John WIley \& Sons: London, 1970.

(2) Uson, R.; Laguna, A.; Laguna, M.; Briggs, D. A.; Murray, H. H.; Fackler, J. P. (Tetrahydrothiophene)Gold(I) or Gold(III) Complexes Inorg. Synth. 1989, 85-91.

(3) Gao, H.-Y.; Wagner, H.; Zhong, D.; Franke, J.-H.; Studer, A.; Fuchs, H. Glaser Coupling at Metal Surfaces Angew. Chem. Int. Ed. 2013, 52, 4024-4028.

(4) Chen, Y.-Y.; Tao, Y.-T.; Lin, H.-C. Novel Self-Assembled Metallo-Homopolymers and Metallo-alt-copolymer Containing Terpyridyl Zinc(II) Moieties Macromolecules 2006, 39, 8559-8566.

(5) Seneclauze, J. B.; Retailleau, P.; Ziessel, R. Design and preparation of neutral substituted fluorene- and carbazole-based platinum(ii)-acetylide complexes $\mathrm{New}$ J. Chem. 2007, 31, 1412-1416.

(6) SAINT V. 7.03A ed.; Bruker AXS Inc.: Madison, WI, USA, 1997-2003.

(7) SADABS; Bruker AXS Inc.: Madison, WI, USA, 2001.

(8) Altomare, A.; Burla, M. C.; Camalli, M.; Cascarano, G. L.; Giacovazzo, C.; Guagliardi, A.; Moliterni, A. G. G.; Polidori, G.; Spagna, R. J. Appl. Crystallogr. 1999, 32, 115-119.

(9) SHELXTL version 5.1; Bruker, AXS Inc.: Madision, WI, 1997.

(10) Gaussian 09, Revision D.01, Frisch, M. J.; Trucks, G. W.; Schlegel, H. B.; Scuseria, G. E.; Robb, M. A.; Cheeseman, J. R.; Scalmani, G.; Barone, V.; Mennucci, B.; Petersson, G. A.; Nakatsuji, H.; Caricato, M.; Li, X.; Hratchian, H. P.; Izmaylov, A. F.; Bloino, J.; Zheng, G.; Sonnenberg, J. L.; Hada, M.; Ehara, M.; Toyota, K.; Fukuda, R.; Hasegawa, J.; Ishida, M.; Nakajima, T.; Honda, Y.; Kitao, O.; Nakai, H.; Vreven, T.; Montgomery, J. A., Jr.; Peralta, J. E.; Ogliaro, F.; Bearpark, M.; Heyd, J. J.; Brothers, E.; Kudin, K. N.; Staroverov, V. N.; Kobayashi, R.; Normand, J.; Raghavachari, K.; Rendell, A.; Burant, J. C.; Iyengar, S. S.; Tomasi, J.; Cossi, M.; Rega, N.; Millam, J. M.; Klene, M.; Knox, J. E.; Cross, J. B.; Bakken, V.; Adamo, C.; Jaramillo, J.; Gomperts, R.; Stratmann, R. E.; Yazyev, O.; Austin, A. J.; Cammi, R.; Pomelli, C.; Ochterski, J. W.; Martin, R. L.; Morokuma, K.; Zakrzewski, V. G.; Voth, G. A.; Salvador, P.; Dannenberg, J. J.; Dapprich, S.; Daniels, A. D.; Farkas, Ö.; Foresman, J. B.; Ortiz, J. V.; Cioslowski, J.; Fox, D. J. Gaussian, Inc., Wallingford CT, 2009.

(11) Hehre, W. J.; Ditchfield, R.; Pople, J. A. Self-consistent molecular-orbital methods .12. further extensions of gaussian-type basis sets for use in molecular-orbital studies of organic-molecules J. Chem. Phys. 1972, 56, 2257-2261.

(12) Hay, P. J.; Wadt, W. R. Ab initio effective core potentials for molecular calculations. Potentials for the transition metal atoms Sc to Hg J. Chem. Phys. 1985, 82, 270-283.

(13) Wadt, W. R.; Hay, P. J. Ab initio effective core potentials for molecular calculations. Potentials for main group elements Na to Bi J. Chem. Phys. 1985, 82, 284-298.

(14) Hay, P. J.; Wadt, W. R. Ab initio effective core potentials for molecular calculations. Potentials for K to Au including the outermost core orbitals. J. Chem. Phys. 1985, 82, 299-310.

(15) Bauernschmitt, R.; and Ahlrichs, R. Treatment of electronic excitations within the adiabatic approximation of time dependent density functional theory Chem. Phys. Lett. 1996, 256, 454-464.

(16) Scalmani, G.; Frisch, M. J.; Mennucci, B.; J. Tomasi, J.; Cammi R.; Barone V. J. Chem. Phys. 2006, 124, 094107.

(17) Tomasi, J.; Mennucci, B.; Cammi, R. Quantum Mechanical Continuum Solvation Models Chem. Rev. 2005, 105, 2999-3094. 